\title{
MISREPRESENTATION: THE RESTATEMENT'S SECOND MISTAKE
}

\author{
Stephanie R. Hoffer*
}

The contract defenses of mistake and misrepresentation can be used to unravel deals as big as a corporate merger and as small as the sale of a used car. These two defenses, while conceptually distinct in theory, contain a significant amount of overlap in practice, causing courts to conflate the two legal standards. A misrepresentation of one party, when believed, results in a mistaken belief of the other, and both defenses address fundamental flaws in bargaining that throw the contracting parties' consent into question. The coextensiveness of the defenses suggests that, absent an overriding normative justification, the legal test and remedy should be the same for each. Such a normative justification exists only in the case of fraudulent misrepresentation which, unlike mistake or nonfraudulent misrepresentation, involves the intentional infliction of a dignitary harm. In such cases, punishment and deterrence are appropriate normative goals but neither are addressed by currently prevailing common law. Providing a single test for cases of misrepresentation and mistake with recourse to punitive damages in cases of fraud would harmonize the defenses with their normative underpinnings and eliminate inefficient redundancies in the common law.

TABLE OF CONTENTS

TAKE

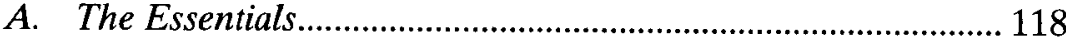

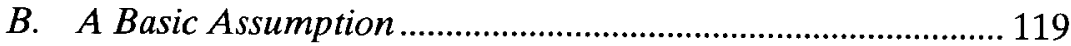

C. Materiality of the Mistaken Assumption.................................. 121

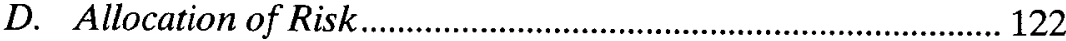

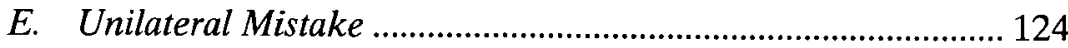

III. MISREPRESENTATION .................................................................. 125

* Associate Professor of Law, The Ohio State University Moritz College of Law. I would like to thank Doug Whaley, Larry Garvin, Michael Kelly, Ellen Deason, Dale Oesterle, and Marc Spindelman for their helpful comments on an earlier presentation of this work. My work also benefitted from the research assistance of Ranaan Lefkowitz, Christopher Matgouranis, Dorothy Roczkowski, and Erik Schumann. All sins of commission and omission are my own. 
A. An Assertion Not in Accord with the Facts ............................ 126

B. Fraudulent or Material Misrepresentation............................ 128

1. Fraudulent Misrepresentation.......................................... 128

2. Material Misrepresentation ................................................ 129

3. Dichotomy on Paper, Mess in Real Life .......................... 129

C. Justified Reliance ..................................................................... 131

D. Inducing Assent of the Counterparty ...................................... 134

IV. MISTAKE AND MiSREPRESENTATION: A COMPARISON OF APPLES TO APPLES? ........................................................................... 136

A. Misrepresentation Results in a Mistaken Belief .................... 137

B. Inducement............................................................................ 138

C. Fraudulence or Materiality ................................................... 141

D. Justified Reliance and Risk Allocation ................................... 143

1. Justified Reliance Is Impossible in the Face of Conscious Ignorance ......................................................... 143

2. Justified Reliance and Express Allocation of Risk ........... 146

3. Justified Reliance and Allocation of Risk by Courts ........ 148

4. Risk of Mistake, Though Similar, Is Broader Than Justified Reliance.

E. Comparison of Remedies: Fraud's Failed Attempt to Go the Extra Mile......................................................................... 151

V. A COMBINED DEFENSE ........................................................... 153

A. A Combined Defense Is Better Than Separate Defenses ....... 153

B. Pushing Back Against a Combined Defense........................... 155

C. Elements of a Combined Defense ....................................... 155

1. Focusing on Adverse Effect .............................................. 156

2. Materiality of the Misconception....................................... 156

3. Protecting Expectations of Counterparties ........................ 157

a. Protecting Counterparties from Conscious Ignorance ... 157

b. Protecting Counterparties Where an Adversely Affected Party Has Explicitly Assumed Risk.

i. Barring a Misrepresentation Defense on the Basis of Explicitly Assumed Risk Prejudices the Adversely Affected Party.

ii. Refusal to Bar a Combined Defense on the Basis of Explicit Assumption of Risk in All Cases Prejudices the Nonadversely Affected Party in Some Cases.

iii. The Assumption of Risk Bar Should Extend Only So

Far As The Parties' Bargained-For Allocation of Risk... 161

D. Choosing a Remedy: Protecting Normative Underpinnings of the Fraud Defense

1. Disgorgement of Profit.

2. Punitive Damages. 165 
a. Tort Law, State Statute, and Restitution in the Noncontractual Context Close Misrepresentation's Normative to Positive Gap .......................................... 165

i. The Tort of Deceit ................................................. 165

ii. Distinguishing Fraud from Nonfraudulent Misrepresentation................................................ 167

iii. State Statutory Protections Against Fraud ............. 170

iv. Restitutionary Remedies in the Noncontractual Context ................................................................ 171

3. Summary on Remedies................................................. 172

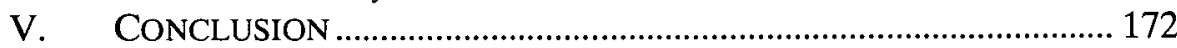

\section{INTRODUCTION}

The Restatement Second of Contracts presents mistake and misrepresentation - two defenses against enforcement of a contract-as related but conceptually distinct doctrines. They are, however, more than mere cousins. Nearly complete overlap in the factual bases for cases of misrepresentation and mistake makes these doctrines more like fraternal twins. The result is confusion among courts, litigants, and students. Consider, for instance, two examples. In the first, Betty acquires a business from Sam (or, if you prefer, B Corp acquires S Corp). Neither party knows that accounting irregularities have caused Sam to grossly overvalue the business' accounts receivable. When Betty discovers this fact, she will try to unravel the deal by raising a defense of mutual mistake. She will do this because both she and Sam have made a faulty assumption about a foundational aspect of the contract. But her case could also be one of material misrepresentation; Sam unintentionally made a material misstatement of fact upon which Betty relied when deciding to acquire the business. So, to reiterate, Betty has two viable defenses: mistake and misrepresentation. Now consider a second example in which Sam is aware of the accounting irregularities and deliberately misleads Betty. This is an obvious case of fraudulent misrepresentation since Sam lied to Betty, but it could also be a case of unilateral mistake, since Betty was laboring under an important false assumption when she acquired the business. Once again, Betty can invoke both mistake and misrepresentation. Notably, under any of these four permutations of Betty's case, she may avoid her contract with Sam, and she may be entitled to restitution. Why, then, do we have two distinct defenses to reach a single result?

This Article makes five claims based on the common ground shared by the contract defenses of misrepresentation and mistake. First, misrepresentation is merely a case of instigated mistake. Second, although their mechanisms are different, mistake and misrepresentation both address the same adverse effect: each produces a failure of consent resulting from 
at least one party's misconception of the facts. Third, because both doctrines take aim at the same failure of consent, the legal test and remedy should be the same for each, absent an overriding normative justification for separating the two. Fourth, there is no compelling normative reason for retaining nonfraudulent misrepresentation as a defense separate from mistake. In such cases, a combined defense would suffice. Finally, while there are compelling normative justifications for retaining fraudulent misrepresentation as a separate concept in contract law, such as punishment and deterrence, the proper way to realize these justifications is not in the determination of a remedy's availability, but rather in the determination of the remedy itself.

Parts II and III of this Article will briefly describe the common law of mistake and misrepresentation. Part IV will compare and contrast these two defenses and will highlight the ways in which redundancies cause courts to conflate them. Part V sets forth justifications for combining the defenses of mistake and misrepresentation and describes how mistake and misrepresentation may be combined into a single defense of misconception. Part VI concludes that a combined defense could preserve and strengthen the unique normative considerations underpinning the fraud defense by permitting courts to award punitive damages in cases of misconception arising through fraud.

\section{MISTAKE}

\section{A. The Essentials}

Mistake occurs when a party to a contract misperceives information that is central to the bargain. As a result, his consent to the bargain is flawed. ${ }^{2}$ For example, if Professor Jacobi purchases a Prius from Professor Bilz believing that it is mechanically sound when the engine is actually a hunk of junk, she has not truly consented to the purchase. Her belief in the car's mechanical integrity is a mistake. ${ }^{3}$ A contracting party who is adversely affected by a mistake, such as Professor Jacobi (who now must pay thousands of dollars to repair the car), can avoid a failed bargain if certain criteria are met. ${ }^{4}$ To be voidable under the Restatement, a contract must involve a mistake "as to a basic assumption on which the contract was made," and the mistake must have "a material effect on the agreed exchange of performances."s In addition, the party seeking to avoid a bargain must not bear the "risk of mistake." In other words, the

1. See RESTATEMENT (SECOND) OF CONTRACTS $\S 151$ (1981) ("A mistake is a belief that is not in accord with the facts.").

2. See id. For an interesting article on failure of consent in mistake cases, see Nancy Kim, Mistakes, Changed Circumstances and Intent, 56 KAN. L. REV. 473 (2008).

3. RESTATEMENT (SECOND) OF CONTRACTS $\$ 151$ (1981).

4. See id. $\$ \$ 152,153$.

5. $I d . \S 152$.

6. Id. 
mistake must regard a matter that is important to the contracting parties, and the party seeking to escape her contractual obligations must not be legally on the hook for the apparent failure of her assumption. Finally, when only one party is mistaken, the contract is not voidable unless one of the following is true: the mistake renders enforcement of the contract unconscionable, the nonmistaken party had reason to know of the mistake, or a fault of the nonmistaken party caused the mistake.

The Restatement formulation of mistake highlights three moving parts: the essential nature of the assumption in question, the materiality of that assumption to the parties' exchange, and allocation of the risk of a mistaken assumption. ${ }^{8}$ Each of these moving parts finds a corollary in the Restatement's formulation of misrepresentation. A comparison of the two defenses will reveal that they differ not in the harm that they seek to redress but in their will to punish a culpable actor. Similarities in the harm and its mechanical production justify consolidation of the two doctrines into one, with culpability of bad actors addressed through an expansion of available remedies. Before reaching that point, it is important to confirm that the two doctrines are, as asserted, essentially two sides of the same coin. What follows is a more detailed discussion of mistake, followed by a similar discussion of misrepresentation.

\section{B. A Basic Assumption}

According to the Restatement, a contract premised on a mistake is not voidable unless the mistake regards "a basic assumption on which the contract was made." Although this language is facially satisfying-we understand that the mistaken assumption must be an important one-it is vague. Does it mean that the assumption is so important that it induced assent? What if it contributed to, but did not induce, assent? What if it regarded a background condition to which the parties never devoted a single thought? Is the inquiry objective or subjective? Courts and commentators have struggled to define the term and to determine when a mistake is fundamental enough to warrant rescission. ${ }^{10}$

The Restatement commentary clarifies the meaning of "basic assumption" somewhat, through both cross-reference to the doctrines of impracticability and frustration of purpose, and through a series of ex-

7. Id. $\$ 153$.

8. Id. $\$ 152 \mathrm{cmt} . \mathrm{a}$.

9. Id. $\S 152(1)$.

10. See, e.g., Reliance Fin. Corp. v. Miller, 557 F.2d 674, 680 (9th Cir. 1977) (stating that the meaning of materiality in cases of mistake and misrepresentation "may really encompass the same facts and concerns, although articulated in different terms"); Melvin A. Eisenberg, Mistake in Contract Law, 91 CALIF. L. REV. 1573, 1575 (2003) (noting that many rules that govern the mistake defense "are either of limited functional significance or are easy to verbally manipulate"); Hoffman F. Fuller, Mistake and Error in the Law of Contracts, 33 EMORY L.J. 41, 91 (1984) (observing that outside of obvious cases, "a court is free to do as it chooses, set loose to sail on an ocean of subjectivity"); James Gordley, Mistake in Contract Formation, 52 AM. J. CoMP. L. 433, 434-42 (2004) (writing that most courts across the world allow relief when a mistake goes to something akin to the basic "substance" of the deal, but the term "substance" is not well understood). 
amples. ${ }^{11}$ Like mistake, both impracticability and frustration address the failure of a basic assumption underlying the contract. ${ }^{12}$ Also like mistake, the Restatement sections applicable to impracticability and frustration define "basic assumption" through cross-reference, this time to U.C.C. $\S 2-615 .^{13}$ This section, which may excuse a party's performance as a result of the failure of presupposed conditions, deals primarily with situations such as failure of a crop or destruction of the goods for which the parties contracted. ${ }^{14}$ As such, it does not shed much light on the meaning of "basic assumption" in the context of mistake, except perhaps to tell us that an assumption is basic when it deals with things at the heart of the deal.

In case law, a basic assumption is one that "relates to the basis of the bargain ....".15 It need not be expressed as part of the agreement. ${ }^{16}$ "In fact, the more basic the assumption, the less likely it is that the assumption will be articulated." 17 It is the "very basis for the contract."18 Furthermore, a basic assumption affects what a party may be willing to accept as consideration for the contract. ${ }^{19}$ Some courts go even further than this, asserting that the mistaken assumption "must go to the essence of the object in view, and not be merely incidental. The court must be satisfied that but for the mistake the complainant would not have assumed the obligation from which he seeks to be relieved." ${ }^{20}$ For instance, the authenticity of a rare violin for purchase ${ }^{21}$ the existence of insurance coverage in a contract for secondary insurance, ${ }^{22}$ the amount of property sold in a real estate transaction, ${ }^{23}$ and the structural integrity of a newly purchased home's foundation ${ }^{24}$ have all been held by courts to be basic assumptions upon which contracts were grounded.

11. RESTATEMENT (SECOND) OF CONTRACTS $\$ 152 \mathrm{cmt}$. b (1981).

12. See Kim, supra note 2, at 473. Defenses based on basic assumption include mutual mistake, unilateral mistake, impossibility, frustration of purpose, and commercial defenses. $I d$.

13. RESTATEMENT (SECOND) OF CONTRACTS, ch. 11, intro. note (1981).

14. U.C.C. §2-615, official cmt (2004).

15. Consol. Rail Corp. v. Portlight, Inc., 188 F.3d 93, 96 (3d Cir. 1999).

16. See Hillside Assocs. of Hollis, Inc. v. Me. Bonding \& Cas. Co., 605 A.2d 1026, 1030 (N.H. 1992).

17. Id.

18. Id.

19. In re Barrister's Land Co., 57 B.R. 863, 866 (Bankr. N.D. Miss. 1985).

20. Knudsen v. Jensen, 521 N.W.2d 415, 418 (S.D. 1994) (emphasis omitted) (quoting Beatty v. Depue, 103 N.W.2d 187, 191-92 (S.D. 1960).

21. See Bentley v. Slavik, 663 F. Supp. 736, 741 (S.D. Ill. 1987) ("[I]t is clear the basic assumption that the violin was a Bernardel materially affected the agreed price, the exchange of performance.").

22. See Hillside Assocs. of Hollis. Inc. v. Me. Bonding \& Cas. Co., 605 A.2d 1026, 1030 (N.H. 1992) (Unknown to the purchaser and insurer, Aetna was already providing requested coverage; thus, the purchaser had no need of insurance, and the bargain was based on a false premise).

23. In re Barrister's, 57 B.R. at 866 ("The quantity of the real property to be conveyed was clearly the 'basic assumption' on which the contract was made....").

24. See Knudsen, 521 N.W.2d at 418 ("Knudsens asked about the fitness of the wooden foundation and were told that Jensens had encountered no problems with the wood foundation and it was possibly the reason the house was so energy efficient. Knudsens entered the contract under the assumption the house was structurally sound."). 
Three case-based observations are in order. First, courts have described a spectrum of gravity when determining whether a mistake regards a basic assumption. On one end of the spectrum is a mistaken belief that affects the amount of consideration the adversely affected party would be willing to accept. On the other end, a mistaken belief is the but-for cause of the adversely affected party's acceptance of a deal. There is no fixed cut-off point at which a mistake rises to the level of a basic assumption. Second, like the analyses of materiality and inducement in misrepresentation, these determinations are highly fact-bound, leaving courts not with a rule that can be consistently applied but with a tremendous amount of discretion to reach a result that reflects the effect of a particular mistake on the parties' exchange of performances. This common law grant of discretion mirrors the ability of courts to draw upon concepts of equity in cases of misrepresentation. Third, judicial determinations of whether an assumption is basic have bled into courts' analyses of a separate Restatement requirement, which is whether the mistaken belief also had a material effect on the parties' performances. As discussed below, a similar analysis of materiality is required in cases of misrepresentation. These three observations militate against the conclusion that mistake is separable from misrepresentation on the grounds that the basic assumption test sets a higher bar than the corresponding portions of the misrepresentation defense. To the contrary, like related portions of the misrepresentation defense, the basic assumption test is a fact-specific moving target that produces an array of decisions more akin to arrows scattered around a bull's eye than to a bright line.

\section{Materiality of the Mistaken Assumption}

A party cannot avoid a contract simply on the basis of a mistaken assumption. The Restatement also requires the mistake to have "a material effect on the agreed exchange of performances" that is adverse to the party who seeks to avoid the bargain. ${ }^{25}$ According to the relevant commentary, this is more than a matter of simply proving that a party would not have entered a contract but for the mistake. ${ }^{26}$ To be material, the mistake must "upset the very basis for the contract." ${ }^{27} \mathrm{Or}$, more explicitly, the party seeking to avoid the deal "must show that the resulting imbalance in the agreed exchange is so severe that he cannot fairly be required to carry it out."28 A party can do this by demonstrating that the contract is less beneficial to her than she expected and more beneficial to the counterparty than the counterparty expected. ${ }^{29}$ For instance, someone who pays top dollar for a counterfeit item can claim that the mistake

\footnotetext{
25. Restatement (SECOND) OF CONTRACTS $\S \S 152,153$ (1981).

26. Id. $\$ 152 \mathrm{cmt} . \mathrm{c}$.

27. Id. $\$ 152 \mathrm{cmt}$. a.

28. Id. $\S 152 \mathrm{cmt}$. c.

29. Id.
} 
had a material effect on the parties' performances. ${ }^{30}$ In such a case, the purchaser receives much less than expected while the seller receives much more. This is a classic case of mistake. Because it hinges on the expectations of the parties, the materiality standard is a flexible one that must take into account the parties' circumstances. ${ }^{31}$

As with the basic assumption requirement, the materiality requirement has a corollary in the doctrine of misrepresentation. In order to render a contract voidable, a misrepresentation must either be fraudulent or material. ${ }^{32}$ "Material," according to the commentary, means likely to induce assent. ${ }^{33}$ Under this definition, a fraudulent misrepresentation will be material in most or perhaps even all cases. This is because a fraudulent representation must be intended to induce assent and must actually do so. ${ }^{34}$ Any representation meeting this bar is also likely to induce assent and is therefore "material" under the Restatement definition applicable in cases of misrepresentation..$^{35}$ As a consequence, we logically may conclude that both mistake and misrepresentation-whether fraudulent or material-contain a materiality requirement. This requirement is explicit in the case of mistake and innocent misrepresentation and de facto in the case of fraudulent misrepresentation.

\section{Allocation of Risk}

Materiality of the basic assumption is not enough to make a case of mistake; the adversely affected party also must show that she does not bear the risk of the mistake. ${ }^{36}$ There are three ways in which the risk of mistake may be allocated to an adversely affected party. ${ }^{37}$ First, she may have assumed the risk explicitly as part of the deal. ${ }^{38}$ Second, she may have contracted with awareness that her knowledge was incomplete. ${ }^{39}$ Courts sometimes refer to this as "conscious ignorance." 40 Third, courts may allocate risk to a party "on the ground that it is reasonable in the circumstances to do so." 41 This generally happens when it is "reasonably clear," based on the court's "general knowledge of human behavior in bargain transactions," that one party should bear the cost of the mistake..$^{42}$

30. See Beachcomber Coins, Inc. v. Boskett, 400 A.2d 78, 79 (N.J. Super. Ct. App. Div. 1979).

31. See RESTATEMENT (SECOND) OF CONTRACTS $\S 152 \mathrm{cmt}$. c.

32. Id. $\$ 164$.

33. See id. $\$ 164 \mathrm{cmt} . \mathrm{c}$.

34. See id. $\$ \S 162,164$. The Restatement commentary, however, suggests otherwise. See id. $\$ 164 \mathrm{cmt}$. a ("[M]ateriality is not essential in the case of a fraudulent misrepresentation."). For additional discussion of this point, see Part II.B.

35. See RESTATEMENT (SECOND) OF CONTRACTS $\$ \$ 162,164 \mathrm{cmt}$. c.

36. Id. $\S 152,153$.

37. Id. $\$ 154$.

38. Id. \$154(a).

39. Id. \$ 154(b).

40. Id. \$ $154 \mathrm{cmt}$. c.

41. Id. § 154(c).

42. Id. \$ $154 \mathrm{cmt}$ d. 
The allocation of risk based on conscious ignorance is similar to misrepresentation's requirement that an adversely affected party's reliance on the misrepresentation be justified. A party acts with conscious ignorance when he is aware of his uncertainty about an aspect of the deal but chooses to contract anyway. ${ }^{43}$ The rule requires a party to discover uncertain facts for himself by reasonable diligence. ${ }^{44}$ For instance, if a buyer knows that a seller is uncertain about a real property's boundary line, but the buyer does not hire a surveyor to ascertain it, relief for the mistake is generally unavailable..$^{45}$ In other words, the buyer has decided that the unknown boundary is an acceptable part of the deal (perhaps demanding a better price in return for the risk he assumes), and he cannot later complain of an undesirable outcome. The rule of justified reliance in misrepresentation is similar. ${ }^{46}$ A party must make at least a cursory investigation of the facts, and some courts have required greater dildiligence from more sophisticated parties. ${ }^{47}$

If parties have neither allocated the risk of mistake by agreement nor assented with conscious ignorance, a court may allocate the risk of mistake using a reasonable basis. ${ }^{48}$ This test, too, overlaps to some extent with misrepresentation's inquiry into justified reliance. Courts have taken multiple approaches to the allocation of risk. Some courts allocate risk of mistake by asking which party had the best opportunity to discover the mistake ${ }^{49}$ and other courts allocate the risk by asking what allocation the parties would have bargained for if they had been aware of the risk. ${ }^{50}$ Risk also may be allocated to the least cost avoider. ${ }^{51}$ Trade cus-

43. See Horney v. Westfield Gage Co., 77 F. App'x. 24, 34 (1st Cir. 2003) (holding that settlement agreement was not invalid where party relied on statement of another that agreement was acceptable instead of reading it himself).

44. See Armco, Inc. v. S. Rock, Inc., 696 F.2d 410, 412-13 (5th Cir. 1983) (holding that party could not void contract where it assumed responsibility for repairing damaged sewer pipe without first investigating who was liable for damage); see also Hunt v. Davis, 45 So. 2d 350, 352 (Miss. 1950) (holding that owner who inadvertently conveyed mineral rights could not avoid contract where inadvertent transfer was a result of owner's own inattention).

45. See Bailey v. Ewing, 671 P.2d 1099, 1102-03 (Idaho Ct. App. 1983). Interestingly, the court granted relief because, although both parties were aware of their uncertainty about the parcel's boundary, neither could have anticipated that it would run directly through the house. The court therefore held that neither party consciously assumed the risk. Id.

46. See infra Part III.C.1.

47. Id.

48. Restatement (SECOND) OF CONTRACTS $\$ 154(\mathrm{c})$ (1981).

49. See Wasser \& Winters Co. v. Ritchie Bros. Auctioneers (Am.), Inc., 185 P.3d 73, 78-81 (Alaska 2008) (holding that secured creditor bore risk because it had a better opportunity and greater reason to discover other lien holders than auctioneer hired to sell property); Estate of Nelson v. Rice, 12 P.3d 238, 242 (Ariz. Ct. App. 2000) (holding that estate bore risk of mistake because it had a better opportunity to discover the value of decedent's art work than purchasers); Beachcomber Coins, Inc. v. Boskett, 166400 A.2d 78, 79-80 (N.J. Super. Ct. App. Div. 1979) (explaining that the defendant claimed that plaintiff should have born risk of loss that coin was a counterfeit because defendant was a coin expert who conducted an inspection); Motorists Mut. Ins. Co. v. Columbus Fin., Inc. 861 N.E.2d 605,610 (Ohio Ct. App. 2006) (holding that insurer bore risk of mistake because it failed to adequately investigate accident).

50. See Dairyland Power Co-op v. United States, 27 Fed. Cl. 805, 813-15 (1993) (holding that buyer of reactor bore risk that spent nuclear fuel reprocessing would not be available in future because the buyer must have been aware of the risk, it had contract allocated numerous other risks to seller, and the seller would not have accepted the risk). 
tom can also affect a court's allocation of risk. ${ }^{52}$ A common thread runs through each of these determinations: in the allocation of risk, courts are interested in who should have avoided the risk, perhaps by bargaining it away, engaging in additional diligence, following standard trade practices, or exercising a base level of care.

The inquiry into whether an adversely affected party should have avoided a particular risk is closely akin to the question of whether the party who heard a misrepresentation should have known better than to rely on it. Similar types of facts and circumstances affect a court's analysis in both cases. For instance, a life insurer that deals with a centenarian surely bears the risk of its mistake about the new customer's ill health. ${ }^{53}$ Likewise, the insurer should not rely on the customer's assertion that he is well because doing so would not be reasonable. Common law allocates the risk to the insurer, and the insurer's reliance would not be justified..$^{54}$ This is because the insurer has superior knowledge about the life expectancy of centenarians, and industry custom would require the insurer to request a medical exam. These facts bar relief under either mistake or misrepresentation, provided that other prongs of each test are satisfied..$^{55}$

\section{E. Unilateral Mistake}

If a mistake is unilateral - the mistaken belief is held by only one party to the bargain - then the adversely affected party must make an additional showing to obtain rescission. ${ }^{56} \mathrm{~A}$ contract is not voidable for unilateral mistake unless the adversely affected party proves that enforcement of the contract would be unconscionable, the counterparty had reason to know of the mistake, or the counterparty's fault caused the mistake. ${ }^{57}$ As with mutual mistake, the adversely affected party must not bear the risk of mistake. ${ }^{58}$ These extra hurdles essentially ask which party is more at fault for the failed bargain, and if no one is at fault, they provide relief only when the result to the adversely affected party is truly drastic. The additional requirements favor an innocent counterparty who does not share in the adversely affected party's mistake. They work

51. See Faivre v. DEX Corp. Ne., 913 N.E.2d 1029, 1038 (Ohio Ct. App. 2009) (adversely affected party argued that counterparty should bear risk of mistake of counterparty's typographical error); Ayer v. W. Union Telegraph Co., 10 A. 494 (Me. 1887) (holding that plaintiff bore the risk of transcription error because he chose the mode of communication); RESTATEMENT (SECOND) OF CONTRACTS $\S 154 \mathrm{cmt}$. d., illus. 3-6.

52. See Beachcomber, 400 A.2d at 79-80 (explaining that the defendant seller claimed that the plaintiff buyer bore the risk because industry custom effectively created an implied contract term that allocated the risk to the buyers); Motorists Mut. Ins. Co., 861 N.E.2d at 610-11 (finding that insurer bore risk of botched settlement because it failed to discover mistake even though its daily business involved identifying parties in motor vehicle accidents).

53. See RESTATEMENT (SECOND) OF CONTRACTS $\$ 154 \mathrm{cmt}$. d, illus. 3.

54. See id.

55. See infra Part III.C.2.

56. See E. Allan Farnsworth \& Larry T. Garvin, Farnsworth on CONTRACTs $\$ 9.4$, at 614 (3d ed. 2004 \& Supp. 2013) (stating that courts are more reluctant to grant relief in these cases).

57. RESTATEMENT (SECOND) OF CONTRACTS $§ 153$ (1981).

58. Id. 
to increase stability and predictability in contracting, and they protect the consent and expectancy interest of the innocent counterparty.

In summary, to avoid a contract on the basis of mistake, a party. must show that he held a false belief about a basic assumption underlying the contract. ${ }^{59}$ This belief must have had a material effect on the parties' exchange of performances, making the contract essentially different from the deal he expected. ${ }^{60}$ Finally, he must not bear the risk of mistake. ${ }^{61}$ In general, the mistake test is similar to the test for misrepresentation. Like mistake, misrepresentation requires a bargaining flaw of sufficient gravity. Also like mistake, misrepresentation shifts the weight of a failed bargain from one party to another by taking into account all relevant facts and circumstances. Although misrepresentation does not deal as explicitly with assumption of risk as mistake does, it nonetheless requires justified reliance on the part of the adversely affected party, and these two inquiries are strikingly similar. It is not surprising that the similarities between these two doctrines are confusing for both courts and litigants and that they create unnecessary redundancies in the law of contracts.

\section{MISREPRESENTATION}

As the prior section demonstrated, misrepresentation overlaps significantly with mistake. But before relegating misrepresentation to the dustbin of history, it is necessary to identify the differences between misrepresentation and mistake that may be worth preserving. This, of course, requires a full examination of the misrepresentation defense. Misrepresentation and mistake cover a great deal of the same territory, but they are not identical.

A contract is voidable for misrepresentation when one party's assent to the bargain is induced by a fraudulent or material misrepresentation of the other party. ${ }^{62}$ The party seeking to avoid the bargain must have been justified in his reliance on the misrepresentation. ${ }^{63}$ The end result is a contract in which one or both of the parties have a mistaken belief regarding the substance or circumstances of the deal. Notably, in some jurisdictions, the adversely affected party need not prove harm in order to avoid the deal. ${ }^{64}$

Like mistake, the defense of misrepresentation has three moving parts: inducement of assent, the fraudulence or materiality of the misrepresentation, and the reasonableness of the adversely affected party's reliance. Unlike mistake, though, misrepresentation focuses not on the weight or effect of the parties' misconception, but rather on the way the misconception was caused. This key distinction makes misrepresentation

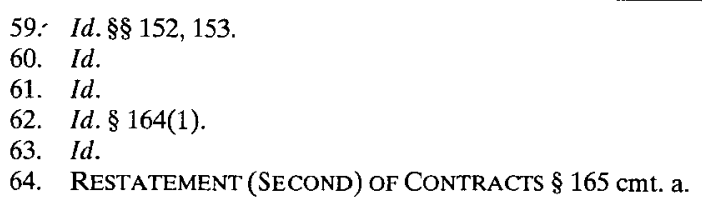


better suited for deterring or punishing bad behavior in bargaining. Misrepresentation's focus on culpability detracts from courts' ability to identify failures in bargaining that are egregious enough to prevent the adversely affected party from consenting. As a result, under current law, the defense of misrepresentation may apply in cases where the defense of mistake would not. In other words, unlike mistake, misrepresentation strongly conflates the question of whether a contract exists or is enforceable with equitable considerations centered on culpability and unjust enrichment that could be more effectively addressed in the consideration of remedies.

The idea that fraudulent misrepresentation is best preserved as a remedy rather than as a separate defense is supported by its origins in equity, and equitable concepts continue to play a significant role in misrepresentation. ${ }^{65}$ It is most apparent in misrepresentation's insistence that the misrepresenting party retain no benefit from the flawed bargain. ${ }^{66}$ Modern misrepresentation is a defense against such a bargain only if three things are true, each of which is described in detail in the following paragraphs: first, one party must have made a false assertion to the other; ${ }^{67}$ second, the incorrect assertion must have been fraudulent or material; ${ }^{68}$ and third, the person seeking to avoid the contract must have been justified in relying on the assertion. ${ }^{69}$

\section{A. An Assertion Not in Accord with the Facts}

To avoid a contract on the basis of misrepresentation as described in the Restatement, an adversely affected party must show that his counterparty made an assertion not in accord with the facts. ${ }^{70}$ In cases involving an express falsehood, this prong is easily met; however, not every case of misrepresentation deals with written or spoken words. Actions

65. The defense of misrepresentation is truly ancient. As early as 1201 , courts recognized a writ of deceit that could apply to "a person who had misused legal procedure for the purpose of swindling someone." See W. PAGE KeETON ET AL., PROSSER AND KEETON ON THE LAW OF TORTS 727-28 (5th ed. 1984). The writ was later superseded by a common law a claim for misrepresentation resulting in actual damage. Id. at 728 . This cause of action covered many cases that now would be considered breaches of contract, and in most cases, the presence of a contractual relationship was a prerequisite to its use. Id. Not until 1789 was the action for deceit found to lie outside the contractual relationship as a purely tort action. Id. Likewise, courts of equity recognized the defenses of misrepresentation and mistake very early on because a party's injuries were often inadequately answered through the legal remedy of damages described above. Id. at 729. The object of equitable remedies, the most common of which were rescission or reformation, was to prevent the maker of a misrepresentation from gaining a benefit from the transaction by restoring the parties to their status quo. Id. When a misrepresentation was material, an adversely affected party could rescind the agreement regardless of the culpability or fault of the counterparty. Id. Courts reasoned that the counterparty should not benefit from a flawed bargain induced by his material misrepresentation. Id. As time passed, the relief afforded by equity also became available in actions at law, blurring the line between the two. Id. at 730 . Courts of law allowed a plaintiff to both rescind a contract and seek restitution damage to recover the value of what he parted with without resorting to a court of equity. $I d$.

66. Id.

67. RESTATEMENT (SECOND) OF CONTRACTS $\$ 159$ (1981).

68. Id. $\$ 164$.

69. Id.

70. Id. § 159. 
and silence may also be considered assertions. ${ }^{71}$ An action is an assertion when it is "intended or known to be likely to prevent another from learning a fact ...." ${ }^{\prime 2}$ For instance, a seller who hides termite damage under the rug when showing a home to a prospective buyer potentially asserts that there is no such damage. ${ }^{73}$ Like other Restatement language regarding misrepresentation, the action-as-assertion test focuses on the state of mind of the party who made the statement instead of the effect of the misrepresentation on the bargain. The maker of a misrepresentation will be punished by a court if he meant to mislead his counterparty or if he knew that the counterparty would be misled. The requirement of a particular state of mind in this context is reminiscent of actions sounding in equity, tort, or criminal law but is a departure from the typical stance of contract law, which purports to favor objective analysis over subjective analysis. ${ }^{74}$

Like the action-as-assertion test, the silence-as-assertion test also focuses on scienter, though not as strongly. Nondisclosure of a fact will be treated as an assertion that the fact does not exist in four situations: (1) where disclosure is necessary to prevent a previous assertion from being a misrepresentation, (2) where the disclosure is necessary to correct a mistake of the other party and failure to disclose would not comport with good faith and reasonable standards of fair dealing, (3) where disclosure would correct a mistake of the other party as to the contents of a writing, and (4) where the counterparty is entitled to know a fact because of a relationship of trust between the parties. ${ }^{75}$ In each of these situations, silence may be treated as a misrepresentation if it misleads the other party. ${ }^{76}$ Each situation also assumes a level of culpability in the party who made the misrepresentation. Although scienter is not explicitly required by the Restatement, each situation is one in which the maker knew or should have known that silence would be unfairly misleading. Furthermore, the silence-as-assertion test focuses not only on the culpability of the maker of the misrepresentation but also on that of the adversely affected party. The commentary provides that "a party need not correct all mistakes of the other and is expected only to act in good faith and in accordance with reasonable standards of fair dealing...., In addition, the adversely affected party must have taken "normal steps to inform himself and to draw his own conclusions. If the other is indolent, inexpe-

71. Id. $\S \S 160,161$; see Lindberg Cadillac Co. v. Aron, 371 S.W.2d 651, 652-53 (Mo. Ct. App. 1963) (holding that an affirmative act of concealment constituted misrepresentation where seller of a car used gasket sealer to conceal cracks in the motor).

72. RESTATEMENT (SECOND) OF CONTRACTS $\$ 160$ (1981).

73. See Hill v. Jones, 725 P.2d 1115, 1117-20 (Ariz. Ct. App. 1986) (holding that seller of home who concealed termite damage could be subject to misrepresentation defense).

74. See, e.g., Lucy v. Zehmer, 84 S.E.2d 516, 521 (Va. 1954) (holding that a buyer could enforce an agreement made informally on a diner tab because an objective observer would have believed that the seller's offer was earnest rather than in jest).

75. RESTATEMENT (SECOND) OF CONTRACTS $\$ 161$ (1981).

76. See id. $\$ 161 \mathrm{cmt}$. a.

77. Id. $\$ 161 \mathrm{cmt}$. d. 
rienced or ignorant, or if his judgment is bad or he lacks access to adequate information, his adversary is not generally expected to compensate for these deficiencies." 78 The strong language is telling. A party must not be permitted to benefit from underhanded dealing, but he also may not escape the consequences of his indolence, ignorance, or bad judgment. This moral consequential focus is far less apparent in the doctrine of mistake and represents an important normative distinction between the two defenses.

\section{B. Fraudulent or Material Misrepresentation}

\section{Fraudulent Misrepresentation}

According to the Restatement, a misrepresentation is actionable only if it is either fraudulent or material. ${ }^{79}$ A misrepresentation is fraudulent when it is intended to induce the other party to enter into the contract and when one of three things is true: (1) the maker knows or believes that the assertion is not true, (2) the maker does not have the confidence that he states or implies in the truth of the assertion, or (3) the maker knows that he does not have the basis that he states or implies for the assertion. ${ }^{80}$ The assertion must be both false and intended to mislead the other party. ${ }^{81}$ Courts refer to the maker's knowledge or recklessness with regard to the false assertion as scienter, a term more commonly used to denote a culpable state of mind in other areas of law such as equity and tort. ${ }^{82}$

The scienter requirement is only one way in which misrepresentation's use of fraud focuses more on the actions of the wrongdoer than on the damage he has caused. In addition to requiring scienter, the Restatement specifies that when an assertion is fraudulent, it need not be material. ${ }^{83}$ According to the Restatement, a fraudulent assertion is actionable even when it would not be important to a reasonable person or to the actual party who hears it,$^{84}$ and it need not be central to the bargain. Why, then, unwind the deal on account of a fraudulent misrepresentation of this nature? Punishment of a culpable actor, or deterrence of future culpable behavior, are the only logical explanations. As dis-

78. Id.

79. Id. $\S 164$.

80. Id. $\$ 162$

81. Id. It is not necessary for the maker of the assertion to know with certainty that the assertion is false. $I d$. cmt. b. It is enough that the maker believes that the statement may be false. $I d$. In such a case, the maker has acted recklessly. $I d$.

82. Id. Scienter is defined as "the fact of an act's having been done knowingly, esp. as a ground for civil damages or criminal punishment." BLACK'S LAW DICTIONARY 1463 (9th ed. 2009).

83. RESTATEMENT (SECOND) OF CONTRACTS $\$ 164$ (1981) (stating that misrepresentation is actionable when it is either fraudulent or material); see also id. $\$ 162 \mathrm{cmt}$. c ("[A] fraudulent misrepresentation need not be material in order to entitle the recipient to relief under the rule stated in $\S 164 \ldots . .$. ).

84. See id. $\$ 162 \mathrm{cmt}$. c (stating that an assertion is material if it is likely to induce a reasonable person to assent or when it regards a matter important to a particular recipient of the assertion). 
cussed below, this conclusion must be softened somewhat because the Restatement requires an adversely affected party to have actually been induced by the statement. Nonetheless, the language and form of the Restatement test for the fraudulence of a misrepresentation focus unabashedly on the actor with unclean hands. This is an important normative distinction between fraudulent misrepresentation and mistake.

\section{Material Misrepresentation}

Like fraudulent misrepresentations, material misrepresentations are also grounds for voiding a contract. ${ }^{85}$ According to the Restatement, a misrepresentation is material if it is likely to induce a reasonable person to agree to the contract, or if the maker knows that it is likely to induce her counterparty to do so. ${ }^{86}$ Like the test for fraudulence, this test focuses on the mindset of the maker of a false assertion rather than the impact of that assertion. ${ }^{87}$ In essence, it asks whether the maker of the false assertion thought that the assertion would be important enough to the other party to induce his or her assent. ${ }^{88}$ Again, the focus is on culpability. The commentary provides that "[o]ne who preys upon another's known idiosyncrasies cannot complain if the contract is held voidable when he succeeds in what he is endeavoring to accomplish." 89 Finally, nonmaterial, nonfraudulent misrepresentations cannot be used as a basis for unwinding a deal..$^{90}$ This is different from the Restatement test for fraud, where the maker of a misrepresentation purportedly may be punished even when her assertion is not material. In other words, the makers of material misrepresentations may be culpable, hence the use of predation as an analogy, but they are still not as culpable as those who engage in fraud.

\section{Dichotomy on Paper, Mess in Real Life}

Although the Restatement and its commentary are relatively clear that a fraud defense may rest on a nonmaterial assertion, it is not likely that such a misrepresentation would be actionable, even under the Restatement's own language. This is because the fraud defense requires more than just a fraudulent communication. It also requires intent to induce $^{91}$ and actual inducement. ${ }^{92}$ Unless the adversely affected party was induced by the fraudulent assertion, a court cannot provide her relief un-

85. Id. $\$ 164$.

86. Id. $\$ 162(2)$.

87. See id.

88. See id.

89. Id. $\S 162 \mathrm{cmt}$. c. The Restatement's use of the word "preys" is particularly interesting since the maker of a material misrepresentation does not have to know with certainty that the statement is false. See id. $\$ 162 \mathrm{cmt}$. b.

90. See id. $\$ 162$.

91. Id. $\$ 162(1)$ (stating that misrepresentation is not fraudulent unless maker intended to induce assent of counterparty).

92. Id. §164(1). 
der the Restatement test. ${ }^{93}$ Put more plainly, a false statement that induces the adversely affected party, i.e., on which he relies when entering into the bargain, must also have some significance to him. Therefore, it is nearly impossible to describe a fraudulent misrepresentation that is not also a material one.

Courts in a number of states agree that a fraudulent misrepresentation must be material in order to render a contract voidable. ${ }^{94}$ Among these courts, the actual meaning of "material" varies. A misrepresentation may be material if it substantially adds to the value of a material interest of the adversely affected party. ${ }^{95}$ A court may also consider whether the misrepresentation affects the purpose of the contract. ${ }^{96}$ Taking a more stringent view, other courts have held that fraud is not mate-

93. Id. No legal effect flows from either a nonfraudulent or a fraudulent misrepresentation unless it induces action by the recipient; that is, unless he manifests his assent to the contract in justifiable reliance on it. $I d . \S 164 \mathrm{cmt}$. b.

94. Crooker v. White, 50 So. 227,228 (Ala. 1909) (stating that to amount to fraud authorizing equity to rescind a contract, misrepresentation must relate to a fact material to the interests of the other party); Melvin v. Stevens, 458 P.2d 977, 980 (Ariz. Ct. App. 1969) (stating that to serve as grounds for rescission of contract, misrepresentation must regard a material fact); Monad Eng'g Co. v. Stewart, 78 A. 598, 600 (Del. Super. Ct. 1910) (stating that to serve as basis for avoidance of contract, fraud must relate to something material); Morris v. Ingraffia, 18 So. 2d 1, 3 (Fla. 1944) (stating that fraud invalidating contract must be made by one contracting party to another respecting matter affecting contract materially); Columbus Hotel Corp. v. Hotel Mgmt. Co., 156 So. 893, 901 (Fla. 1934) (stating that to invalidate contract, misrepresentation must refer to a matter affecting contract materially); Sutton v. Crane, 101 So.2d 823, 825 (Fla. Dist. Ct. App. 1958) (stating that to serve as basis of rescission, misrepresentation must refer to a matter affecting contract materially); Crowell v. Brim, 12 S.E.2d 585, 587 (Ga. 1940) (stating that rescission allowed where fraud consists of misrepresentation of a material fact as to subject matter of contract); Kloppenburg v. Mays, 88 P.2d 513, 519 (Idaho 1939) (stating that relief from contract is available in cases of fraudulent representation of a material fact); Schwaner $v$. Belvidere Med. Bldg. P'ship, 508 N.E.2d 522, 529 (Ill. App. Ct. 1987) (stating that to constitute "fraud in the inducement" and invalidate contract, representation must be one of material fact); Grane v. Grane, 473 N.E.2d 1366, 1373 (Ill. App. Ct. 1985) (stating that representation must be one of material fact to invalidate contract); Glass Coffee Brewer Corp. v. Embry, 166 S.W.2d 818, 823 (Ky. 1942) (stating that representations must be material to contract itself, as distinguished from matters which are merely collateral); 46th Circuit Trial Court v. Crawford Cnty., 702 N.W.2d 588, 597 (Mich. Ct. App. 2005) (stating that to raise fraud defense against enforcement of contract, "claimant must prove that it actually relied upon a material misrepresentation"); Cardinal v. Dimit, 69 N.E.2d 65, 67 (Ohio Ct. App. 1945) (stating that to present a defense, fraud must relate to a material matter in the contract); United Jersey Bank v. Wolosoff, 483 A.2d 821, 826 (N.J. Super. Ct. App. Div. 1984) (stating that to claim rescission on the basis of fraud, adversely affected party must prove material misrepresentation of a presently existing or past fact); First Nationwide Bank v. 965 Amsterdam, Inc., 623 N.Y.S.2d 200, 201 (N.Y. App. Div. 1995) (stating that material representation is an element of fraud defense); Almap Holdings, Inc. v. Bank Leumi Trust Co. of N.Y., 601 N.Y.S.2d 319, 320 (N.Y. App. Div. 1993) (stating that no fraud defense absent proof that defendant misrepresented material fact ); Seyfried v, Greenspan, 459 N.Y.S.2d 316, 319 (N.Y. App. Div. 1983) (stating that to constitute fraud or mutual mistake, facts misrepresented or "facts about which the parties are mutually mistaken must be material facts"); Dozier v. Hawthorne Dev. Co., 262 S.W.2d 705, 709 (Tenn. Ct. App. 1953) (stating that fraud is ground for rescission only where representation was so material that it determined conduct of party seeking relief); International Life Ins. Co. v. Herbert, 334 S.W.2d 525, 530 (Tex. Civ. App. 1960) ("[C]ourt will be governed by the materiality of the fraud alleged to the contract sought to be avoided."); Dawson v. Lohn, 705 P.2d 853, 857 (Wyo. 1985) (stating that misstatement must be material to support a claim of fraud).

95. See Crooker, 50 So. at 228 (explaining that a misrepresentation must affect the value of the contract to the adversely affected party).

96. See Security-First Nat. Bank of L.A. v. Schaub, 162 P.2d 966, 971 (Cal. Dist. Ct. App. 1945) (finding that a misrepresentation is material if it relates to a matter of substance and directly affects the purpose of the adversely affected party). 
rial unless the adversely affected party would not have assented to the deal without it. ${ }^{97}$ Finally, a few courts have agreed with the Restatement position that materiality is not necessary to the fraud defense. ${ }^{98}$ These decisions, however, seem to be in the minority. Most cases more closely mirror the defense of mistake, which requires materiality for successful invocation.

\section{Justified Reliance}

Under the Restatement test, a contract cannot be avoided simply on the basis of a fraudulent or material misrepresentation. The adversely affected party must also show that the misrepresentation induced his assent to the deal and that he was justified in relying on it. ${ }^{99}$ According to the Restatement commentary, the justified reliance requirement is generally met if the assertion at issue is not one of opinion, law, or intention. ${ }^{100}$ In addition, reliance is not justified if the assertion regards a matter about which the maker should not take seriously. ${ }^{101}$ Finally, reliance on statements of "peripheral importance" to the transaction is not justified. ${ }^{102}$

Like the Restatement, older cases on the subject of misrepresentation permitted an adversely affected party to rely on any intentionally false assertion of the counterparty. ${ }^{103}$ As the court in Chamberlain $v$.

97. See Great Am. Ins. Co. of N.Y. v. Suarez, 109 So. 299, 301 (Fla. 1926) (stating that fraudulent misrepresentation is material only if contract would not have been executed but for misrepresentation); Coffey v. Hendrick, 65 S.W. 127, 128 (Ky. 1901) (holding that a contract to buy books should not be enforced where a seller misrepresented that the book was copyrighted, and the buyer would not have purchased the book otherwise); Lane v. Harmony, 90 A. 546, 548 (Me. 1914) (stating that fraud is material only if "had it not been practiced the contract would not have been made"); McAleer $v$. Horsey, $35 \mathrm{Md}$. 439, 452 (1872) (fraud is material to the contract when the contract would not have been made but for fraud); Greenwood v. Kadoich, 357 A.2d 604, 607 (Pa. Super. Ct. 1976) ("[M]isrepresentation is material when it is of such a character that if it had not been made, the transaction would not have been entered into."); Sawyer v. Pierce, 580 S.W.2d 117, 124 (Tex. Civ. App. 1979) (stating that a misrepresentation is material only if it induced the adversely affected party to enter contract). C.f. First State Bank of Bellaire v. Olde Colony House, Inc., 414 S.W.2d 221, 223 (Tex. Civ. App. 1967) (stating that to avoid a contract, it is not necessary that fraud be the sole reason for making contract; it is sufficient that adversely affected party "relied on [the misrepresentation] to the extent that it was a material factor in inducing the making of the contract and without which the same would not have been made").

98. See, e.g., De Joseph v. Zambelli, 139 A.2d 644, 647 (Pa. 1958) ("Fraud renders a transaction voidable even where the misrepresentation is not material ... ."); Clement Martin, Inc. v. Gussey, 157 A.2d 412, 415 (Pa. Super. Ct. 1959) ("Fraud renders a transaction voidable even where the misrepresentation is not material."); Long v. State Farm Fire \& Cas. Co., 510 S.W.2d 517, 519 (Tenn. Ct. App. 1974) ("[F]raud is never immaterial.").

99. RESTATEMENT (SECOND) OF CONTRACTS $\$ 164$ (1981).

100. Id. $\$ 164 \mathrm{cmt} . \mathrm{d}$.

101. Id.

102. Id.

103. See, e.g., Eichelberger v. Mills Land \& Water Co., 100 P. 117, 121 (Cal. Ct. App. 1908) (finding that when a misrepresentation is intentional, the misrepresentation defense is not barred by adversely affected party's failure to investigate suspicious circumstances); Sutton v. Greiner, 159 N.W. 268,271 (Iowa 1916) (holding that a party making intentional misrepresentation is barred from asserting that "his false statement ought not to have been believed"); Alfred Shrimpton \& Sons v. Philbrick, 55 N.W. 551, 551 (Minn. 1893) (holding that a defrauded party may raise the misrepresentation defense against contract even though he failed to exercise ordinary business prudence in executing it); 
Fuller explained, "No rogue should enjoy his ill-gotten plunder for the simple reason that his victim is by chance a fool." 104 Modern cases, however, typically require the adversely affected party to employ at least a modest level of investigation and prudence. Modern courts sometimes state the justified reliance inquiry in two parts: did the adversely affected party rely on the misrepresentation and, if so, was that reliance justified? ${ }^{105}$ Courts have varied in their application of the requirement and have established a spectrum of possible rulings. On one end of the spectrum, a court may hold that where the representation was material to the adversely affected party, that party's reliance is presumed to be justified unless rebutted. ${ }^{106}$ On the other end, a court may require a level of investigation commensurate with the adversely affected party's level of business sophistication. ${ }^{107}$ Most courts, however, seem to occupy a middle ground, requiring at least a cursory investigation into the truth of a counterparty's assertions but not a full-blown fact-finding mission. ${ }^{108}$ In other words, an adversely affected party cannot rely blindly on the counterparty's assertion. ${ }^{109}$ Instead, he must exercise ordinary diligence to determine the truth. ${ }^{110}$ If the adversely affected party was given a reasonable

Pac. Maxon, Inc. v. Wilson, 619 P.2d 816, 818 (Nev. 1980) ("[A]n intentional false representation which is relied upon in fact, is all that is required" to void contract on the basis of fraud); Johnson v. Cofer, 281 P.2d 981, 985 (Or. 1955) ("[I]t is better to encourage negligence in the foolish than fraud in the deceitful.").

104. 9 A. 832,836 (Vt. 1887).

105. 7 JOSEPH M. PERILlo, CORBIN ON CONTRACTS $\S 28.15$, at 75 (rev. ed. 2002) (stating that the two main issues in reliance are whether the person who was deceived has a right to rely and whether he or she actually relied).

106. See Miller v. Celebration Mining Co., 29 P.3d 1231,1235-36 (Utah 2001) (finding that where a seller purported to be the president of a defunct mining company but was actually selling real property in his personal capacity, no evidence rebutted the presumption that the adversely affected party relied on representation that seller was a corporation rather than an individual); see also 7 PERILLO, supra note $105, \S 28.15$, at 75 ("[A] material misrepresentation gives rise to a rebuttable presumption of deception and reliance.").

107. See Marine Bank Nat'l Ass'n v. Meat Counter, Inc., 826 F.2d 1577, 1582 (7th Cir. 1987) (where adversely affected party was a business owner, jury could have found that he was "sophisticated enough to know" that representation was inaccurate); Peterson v. Swain, No. CV055001192S, 2010 WL 1795883, at *9-10 (Conn. Super. Ct. 2010) (finding that a genuine issue of material fact existed as to whether the lessees of a car could have discovered its lessor's misrepresentation through a cursory investigation).

108. See Brown v. Wells Fargo Bank, 85 Cal. Rptr. 3d 817, 833 (Cal. Dist. Ct. App. 2008) (finding that contract is not void due to fraud if adversely affected party had reasonable opportunity to discover truth); Mims v. Cooper, 46 S.E.2d 909, 910-11 (Ga. 1948) (stating that an adversely affected party must exercise ordinary diligence in effort to discover the fraud); Taggart v. Claxton, 318 S.E.2d 208, 210 (Ga. Ct. App. 1984) (stating that the adversely affected party must prove that he exercised due care to discover the fraud); Gherity v. Brewer, No. A06-2198, 2008 WL 763095, at *3 (Minn. Ct. App. March 25, 2008) ("[T]he fact-finder may consider the context in which a representation is made; it is no excuse to "close [one's] eyes to the realities of the situation."') (quoting Burnes v. Valene, 214 N.W.2d 686, 690 (Minn. 1974)).

109. See Peterson v. Swain, No. CV055001192S, 2010 WL 1795883, at *10 (Conn. Super. Ct. 2010) (holding that a car dealership could not rely on twenty-five year old man's assertion that he was a sixty-seven year old dentist born in 1937 when a cursory investigation would have revealed the falsehood).

110. See, e.g., Mims, 46 S.E.2d at $910-11$ (Ga. 1948) (finding that an adversely affected party must exercise ordinary diligence in effort to discover fraud); Hlavna v. United Bank, 397 N.W.2d 157 (Wis. Ct. App. 1986) (holding that a lender's reliance was justified when lender asked borrower about the 
opportunity to discover the misrepresentation, his reliance on it is unreasonable. ${ }^{111}$

The parties' course of negotiation and course of dealing also factor into a court's assessment of justified reliance. ${ }^{112} \mathrm{~A}$ court is more likely to find that reliance was justified where the parties have maintained a relationship of trust with one another. ${ }^{113}$ For instance, business partners may be entitled to rely upon one another's representations. ${ }^{114}$ Similarly, where one party has specialized knowledge, courts are more likely to find a counterparty's reliance on statements related to that knowledge to be justified. ${ }^{115}$ The parties' negotiations may not be so straightforward, though. If an adversely affected party conducts its own investigation, a court may refuse to find reliance, whether justified or not. ${ }^{116}$ Similarly, disclaimers in a contract or explicit waivers of reliance may defeat the misrepresentation defense. ${ }^{117}$ In this regard, courts' justified reliance re-

intended use of the purchased property, and borrower's reply was retail shopping when true intended use was an adult book store).

111. See, e.g., Sununu v. Philippine Airlines, Inc., 792 F. Supp. 2d 39, 56 (D.D.C. 2011) (suggesting that reliance was not reasonable when the truth could have been discovered by perusal of publicly available financial filings and through conversations with counterparty); Taggart v. Claxton, 318 S.E.2d 208, 210 (Ga. Ct. App. 1984) (stating that a party who alleges fraud must show also that he exercised due care to discover fraud and relied on false representations to his injury); see also Wells Fargo Bank, 85 Cal. Rptr. 3d at 833 (stating that in cases of fraud in execution, a contract is not considered void due to fraud if the plaintiff had a reasonable opportunity to discover the true terms of the contract).

112. See Industrial Commercial Elec., Inc., v. McLees, 101 P.3d 593, 601 (Ala. 2004) (stating that the fact that the adversely affected party employed the misrepresenting party under a settlement evidenced relationship of trust and allowed for justified reliance).

113. See id.; Columbus Hotel Corp. v. Hotel Mgmt. Co., 156 So. 893, 901 (Fla. 1934) (stating that an adversely affected party cannot rely when counterparty "was obviously hostile to the hearer and interested in misleading him").

114. See Allen v. Sanders, 337 S.E.2d 428, 430 (Ga. Ct. App. 1985) (finding that the relationship between partners in business entitles them to rely on one another's representations).

115. See Thomas v. Grise, 41 A. 883, 885 (Del. Super. Ct. 1898) (stating that false representations knowingly made by a party of a material fact "peculiarly within his own knowledge, and in respect to which the other party, in the exercise of proper vigilance, had not a reasonable opportunity of ascertaining the truth," constitute fraud vitiating a contract induced thereby); Bass v. Seaboard Air Line R. Co., 53 S.E.2d 895, 901-02 (Ga. 1949) (finding that a patient has right to rely on statements of an attending physician); Safety Cas. Co. v. McGee, 127 S.W.2d 176, 178 (Tex. Comm'n. App. 1939) (stating that a party with inferior knowledge of the law may justifiably rely on a party who has superior knowledge of the law if the latter took advantage of the former's ignorance in order to mislead him).

116. See Re v. Diamond, 292 N.Y.S. 54, 54 (N.Y. App. Div. 1936) (finding there was no justified reliance where plaintiff relied on investigation made by own lawyer and not on misrepresentation of counterparty); see also 7 PERILLO, supra note 105 , $\$ 28.15$, at 77 . ("[W] here the party receiving the representation in fact makes a personal investigation, many courts have ruled that, as a matter of law, there is no reliance."). Professor Corbin notes, however, that "a perfunctory investigation by a nonexpert does not rule out a finding of reliance." Id.

117. See, e.g., MBIA Ins. Corp. v. Royal Indem. Co., 426 F.3d 204, 211-12 (3d Cir. 2005) (finding that reliance on a representation was not reasonable where the adversely affected party explicitly waived all defenses based on reasonable reliance); Italian Cowboy Partners, Ltd. v. Prudential Ins. Co. of Am., 341 S.W.3d 323, 336 (Tex. 2011) (finding that a merger clause in a contract does not bar evidence of fraud under the parole evidence rule unless it provides that there was no reliance on statements made prior to signature of the written document); Columbus Hotel Corp. v. Hotel Mgmt. Co., 156 So. 893, 901 (Fla. 1934) (finding that an adversely affected party has no right to rely where "the transaction was entered into upon the express understanding of both parties that a material fact might exist of which one of them was ignorant, or where a party has expressly said that he would not be bound by his representations ... or where the representations are "accompanied by a qualified statement which shows that the person making it does not intend that it shall be relied on ...."); McCartin 
quirement strongly resembles the analysis of assumption of risk in mistake cases.

As with misrepresentation, courts analyzing cases of mistake may ask whether the mistaken party should have known of, or could have prevented, the mistake. Generally speaking, in either defense, a party will not be faulted for reliance as long as his failure to discover the truth is not the result of bad faith or failure to act in accordance with reasonable standards of fair dealing. ${ }^{118}$ Here, even the Restatement commentary equates mistake and misrepresentation. It provides, "the mere fact that [the adversely affected party] could, by the exercise of reasonable care, have avoided the mistake caused by the misrepresentation does not bar him from relief. The rule is similar to that applicable to mistake in general, ${ }^{119}$ "and its justification is particularly strong since here the recipient's mistake is the result of a misrepresentation." 120 As a consequence, this prong of misrepresentation arguably could be subsumed by the defense of mistake.

\section{Inducing Assent of the Counterparty}

A contract cannot be voided simply on the basis of a fraudulent or material misrepresentation even if the adversely affected party was justified in relying on it. Inducement is a question of fact that may be proven through direct testimony or circumstantial evidence. ${ }^{121}$ This final prong of the misrepresentation defense requires the adversely affected party to prove that a misrepresentation induced his assent to the bargain. ${ }^{122}$ In other words, the adversely affected party must have agreed to the deal in reliance on the maker's statement. ${ }^{123}$ She does not have to show that she would not have entered the deal but for the assertion. ${ }^{124}$ The misrepresentation must have substantially contributed to her decision, but it need not have been the turning point. ${ }^{125}$ For instance, in one widely reported

v. Westlake, 630 N.E.2d 283, 289-90 (Mass. App. Ct. 1994) (finding that reliance was not reasonable where the adversely affected parties received disclosure statement warning them of need to investigate).

118. RESTATEMENT (SECOND) OF CONTRACTS $§ 172$ (1981).

119. Id. $\$ 157 \mathrm{cmt}$. a.

120. Id. $\$ 172 \mathrm{cmt}$. a.

121. See id. \$ $164 \mathrm{cmt}$. c; see also Industrial Commercial Elec., Inc., v. McLees, 101 P.3d 593, 600 (Ala. 2004) (finding inducement based on testimony that during the settlement negotiation, the attorney for the adversely affected party made it clear that the employer who released the employee from liability was relying on the employee's representation that he had returned the employer's property); Pennsylvania Truck Line, Inc. v. Hendricks, 1986 WL 3969, at *2 (Del. Sup. Ct. Mar. 26, 1986) (finding that the defendant's trial testimony established that but for the plaintiff's misrepresentation about the allocation of risk in a contract, the defendant would not have agreed to contract).

122. RESTATEMENT (SECOND) OF CONTRACTS $\$ 164$ (1981).

123. Id. $\$ 164 \mathrm{cmt}$. c; see also Sununu v. Philippine Airlines, Inc., 792 F. Supp. 2d 39, 56-57 (D.D.C. 2011) (finding that a misrepresentation claim was not appropriate where claimant discovered misrepresentation and contracted anyway); 46th Cir. Trial Ct. v. Crawford Cnty., 702 N.W.2d 588, 597 (Mich. Ct. App. 2005) (dismissing a fraud defense due to "a lack of actual reliance" on the counterparty's misrepresentation).

124. RESTATEMENT (SECOND) OF CONTRACTS $\$ 167 \mathrm{cmt}$. a (1981).

125. Id. \$167. 
Illinois case, a woman's assertion that Michael Jordan was her child's father induced Jordan to enter into a settlement agreement with her. ${ }^{126}$ When Jordan sought to avoid the settlement on the basis of fraudulent misrepresentation, she argued that her assertion of paternity was not the but-for cause of Jordan's agreement. ${ }^{127}$ Rather, Jordan was also induced by her promise to keep their relationship a secret. ${ }^{128}$ The court held that because the misrepresentation regarding paternity was material, it must have influenced Jordan's decision to enter into the settlement agreement. ${ }^{129}$ The court found it irrelevant that the paternity allegation was not Jordan's sole motivation; the misrepresentation was an inducement and need not have been the only influence. ${ }^{130}$

In the Jordan case, as in most cases, the inducement requirement is closely intertwined with the materiality prong of the misrepresentation test. ${ }^{131}$ For instance, in Utah, if there is a material misrepresentation, courts presume that the misrepresentation induced assent. ${ }^{132}$ Likewise, according to the Restatement commentary on inducement, "[i]t is assumed, in the absence of facts showing the contrary, that the recipient attached importance to the truth of a misrepresentation if it was material, but not if it was immaterial." ${ }^{133}$ More simply put, if the misrepresentation regarded an important matter, the adversely affected party is presumed to have relied on it in the absence of evidence to the contrary. ${ }^{134}$ As discussed below, this assumption makes it nearly impossible to avoid a contract for non-material fraudulent misrepresentation, despite the claims of numerous commentators. ${ }^{135}$

Inducement is tied not only to materiality but also to reliance. A party who did not rely on a misrepresentation cannot have been induced by it and vice versa. For instance, a party who inquires about a particular aspect of a deal is likely to be induced by any misrepresentations given in response to the inquiry. ${ }^{136}$ In contrast, a party who conducted a sufficient independent investigation of the false assertion may not assert a misrep-

\footnotetext{
126. See Jordan v. Knafel, 378 I1l. App. 3d 219, 229-30 (2007).

127. Id. at $229-30$.

128. Id. at 230 .

129. Id.

130. Id.

131. See RESTATEMENT (SECOND) OF CONTRACTS $\$ 167 \mathrm{cmt}$. b (1981).

132. See Miller v. Celebration Mining Co., 29 P.3d 1231, 1235 (Utah 2001) (finding that a misrepresentation about identity of contracting party was material, which caused the court to presume inducement "in the absence of facts showing the contrary").

133. RESTATEMENT (SECOND) OF CONTRACTS $\$ 167 \mathrm{cmt}$. b (1981).

134. See 7 PERILLo, supra note $105, \$ 28.15$, at 75 ("[A] material misrepresentation gives rise to a rebuttable presumption of deception and reliance.").

135. See supra Part II.B.

136. See Hutchins v. Cleveland Mut. Ins. Co., 11 Ohio St. 477,479 (1860) (adversely affected party's inquiry "shows that he deems it to be material, and shows that the answer may induce him to take or refuse the risk ... "); Market St. Grp. v. McComb, No. 97 CA51, 1998 WL 404478, at *9 (Oh. Ct. App. 1998) (finding that repeated inquiries by the defendant about misrepresented fact proved that he defendant was induced by the misrepresentation).
} 
resentation defense. ${ }^{137}$ A court may conclude that a party relied on information that was likely to have been disclosed during her inquiry rather than on the misrepresentation itself. ${ }^{138}$ Put in more pragmatic terms, if the adversely affected party should have known better, she cannot avoid the contract. Once again, culpability plays a role in the outcome. The Restatement seeks to punish the maker of a misrepresentation but only if the hearer is not also at fault for the resulting mistaken belief. This result is similar to that produced by a court's assignment of the risk of mistake in cases where the parties have not explicitly allocated it.

\section{MistaKe AND MisREPRESENTATION: A COMPARISON OF APPLES TO APPLES?}

Mistake and misrepresentation are strikingly similar. They apply to similar facts, result in rescission, and to some extent, share normative justifications. Consider a common example: a purchaser agrees to buy land of a particular acreage and she later discovers that the parcel's borders are in dispute, or are not located where the seller represented them to be. There are clear normative grounds for allowing the purchaser to avoid the contract. She has not received the consideration for which she bargained; she did not consent to the transaction as it stands; and if the purchaser is unable to avoid the contract, the seller will have benefited from an intentional or negligent misstatement. The doctrine of mistake may apply if the purchaser has a mistaken belief about a basic assumption underlying the contract. ${ }^{139}$ Misrepresentation may also apply because the seller misspoke when describing the parcel's borders. ${ }^{140}$ In either case, the available remedy will be a declaration that the contract is voidable, perhaps coupled with restitution if the purchaser has already conferred a benefit upon the seller. These similarities justify an analysis of whether both theories are needed or whether they could be combined into a single defense.

The requirements of misrepresentation are, to a large extent, coextensive with those of mistake. Mistake's basic assumption test finds a corollary in misrepresentation's requirements for materiality and actual inducement; mistake's requirement of a material effect on the party's performances is functionally equivalent to misrepresentation's requirement of fraudulence or materiality; and mistake's requirement of risk allocation produces, in many cases, the same result as misrepresentation's requirement of justified reliance. There is, however, an important dis-

137. See John Hancock Mut. Life Ins. Co. of Bos., Mass. v. Cronin, 51 A.2d 2, 5 (N.J. 1947) ("One cannot secure redress for fraud where he acted in reliance upon his own knowledge or judgment based upon an independent investigation.").

138. Id. The presumption also does not apply if the misrepresentation regards a fact that ordinarily would not be uncovered by an investigation of the kind conducted by the adversely affected party. Id.

139. See, e.g., Speedway Enter., Inc. v. Hartsell, 251 P.2d 641, 644 (Ariz. 1952); Dixon v. Morse, 463 P.2d 284, 285 (Idaho 1969); RESTATEMENT (SECOND) OF CONTRACTS $\$ 152$ (1981).

140. See RESTATEMENT (SECOND) OF CONTRACTS $\$ 159 \mathrm{cmt}$. a (1981). 
tinction. The primary focus of mistake is the failed bargain, ${ }^{141}$ whereas misrepresentation's primary focus is culpable behavior by the maker of the misrepresentation. ${ }^{142}$ This distinction does not justify the retention of misrepresentation as a separate contract defense, particularly since misrepresentation's normative stance amounts to little more than ineffectual posturing. Rather, it justifies provision of a broader array of remedies within a combined defense.

As a starting point for comparison of the two defenses, the following paragraphs discuss each prong of the misrepresentation test and ask whether an adequate substitute can be found within mistake. I have chosen this format because mistake applies to a wider spectrum of fact patterns than misrepresentation does. All cases of misrepresentation involve an adversely affected party's mistaken belief about the facts, whereas not all cases of mistake involve a misrepresentation by one of the parties. In other words, all cases of misrepresentation involve a mistake, but not all cases of mistake involve a misrepresentation. Consequently, it is logical to ask whether misrepresentation might be subsumed by mistake but not vice versa.

\section{A. Misrepresentation Results in a Mistaken Belief}

The Restatement's definitions of mistake and misrepresentation overlap considerably. A misrepresentation is an assertion that is not in accord with the facts, ${ }^{143}$ whereas a mistake is a belief not in accord with the facts. ${ }^{144}$ These definitions are related. If a misrepresenting party successfully asserts something that is not in accord with the facts, her counterparty will hold a resulting belief that is not in accord with the facts. In such a case, a misrepresentation of one party causes the mistake of the other. ${ }^{145}$ This endogeneity has led one British commentator to refer to misrepresentation as "really a sub-category of mistake: induced mistake."146

Still, these two foundational aspects of mistake and misrepresentation are not identical. Mistake requires an erroneous belief. ${ }^{147}$ It focuses on the state of mind of the adversely affected party and asks whether that

141. See Part II.A.

142. See Part III.B.2.

143. Id. \$ 159.

144. Id. \$151.

145. Of course, the question of whether either defense is actionable will depend on the tests' remaining factors.

146. John CARTWRIGHT, MISREPRESENTATION 2 (Sweet and Maxwell 2002). Of course, not every mistake is a misrepresentation. It is possible for one or both parties to arrive at a mistaken belief without any communication whatsoever. See Duncan v. New York Mut. Ins. Co., 138 N.Y. 88, 92 (1893) (affirming the cancellation of the rescission of an insurance policy on a marine vessel that was actually shipwrecked, but which insurers and ship owners believed was safe at the next port.); Seidman v. New York Life Ins. Co., 296 N.Y.S. 55, 56-57 (N.Y. Special Term 1937) (rescinding the reduction of a disability insurance policy because both parties were operating under the assumption that the disabled individual was not fully disabled).

147. RESTATEMENT (SECOND) OF CONTRACTS \& 151 (1981). 
party adequately understood the substance of his bargain. Misrepresentation, on the other hand, requires an erroneous assertion. ${ }^{148}$ Instead of focusing on the adversely affected party, the defense focuses on culpable behavior of the representation's maker. The distinction between the definitions of mistake and misrepresentation is seconded by the Restatement commentary, which alleges that actual harm is required for the defense of mistake but not for the defense of misrepresentation. ${ }^{149}$ In other words, although both tests target the same harm stemming from the same failure of consent or consideration, they move toward a remedy from opposite directions. Mistake focuses on the actual misconception, while misrepresentation asks whether the misconception arose through the fault of another party.

The different foci of the Restatement's definitions of mistake and misrepresentation hint at a foundational divergence between the two defenses. Mistake's focus on an adverse effect and misrepresentation's focus on the cause of that effect reflect two approaches to comprehending fault in contract law. ${ }^{150}$ While the distinction arguably stems from misrepresentation's dual origin at law and in equity, its persistence suggests possible normative grounds for retaining a means of punishing or deterring nonnormative behaviors in the bargaining process. Any attempt to combine the defenses must either rebut or be reconciled with this point. A combined defense that eliminates misrepresentation's separate definition because it is functionally subsumed by mistake would lose some embodiment of misrepresentation's historical and normative meaning. A later section will consider whether this is a loss for which gains in clarity and efficiency are adequate compensation, and it will conclude that provisions should be made to strengthen punishment and deterrence of fraud in the combined defense. ${ }^{151}$

\section{B. Inducement}

A second element of misrepresentation requires an adversely affected party to prove that the false assertion induced him to enter the contractual relationship. ${ }^{152}$ The misrepresentation need not have been the but-for cause of the contract, but the adversely affected party must have relied on it when making her decision. ${ }^{153}$ This prong of the test, like the last, focuses on the bargaining process and the parties rather than the result of the flawed bargain. An adversely affected party can only avoid the bargain if his reliance contributed to his injury. Once again, misrep-

148. Id. $\$ 159$.

149. See id. $\$ 152 \mathrm{cmt}$. c; id. § 164. Cf. Kloppenburg v. Mays, 88 P.2d 513, 519 (Idaho 1939) (stating that to obtain rescission on the basis of fraud, the adversely affected party must prove injury by a preponderance of the evidence).

150. See Omri Ben-Shahar and Ariel Porat, Foreword: Fault in American Contract Law, 107 MICH. L. REV. 1341, 1342 (2009) (describing debate among scholars over role of fault in contract law).

151. See infra Part V.D.

152. Id. § 164; see supra Part II.D.

153. Id. $\$ 167 \mathrm{cmt}$. a. 
resentation embodies an idea common in tort: recovery is only available if one party's act caused the other's injury. ${ }^{154}$

The mistake defense does not incorporate a similar requirement. Unlike misrepresentation, it focuses on the harm resulting from the flawed bargaining process. In essence, it asks whether the misconception of the adversely affected party has produced a failure of consent or consideration. ${ }^{155}$ Nonetheless, it reaches the same functional result as misrepresentation by requiring that the mistake at issue regard a basic assumption on which the contract is based and that the mistake materially affect the performances of the parties. ${ }^{156}$ In pragmatic terms, the basic assumption and materiality requirements should adequately cover misrepresentation's inducement requirement because any mistake that meets these two criteria is likely to have induced the adversely affected party to enter into the deal for purposes of the misrepresentation defense.

Although courts have held that the standard for mistake is more stringent than that for misrepresentation, in practice they are nearly coextensive. ${ }^{157}$ In Shore Builders v. Dogwood, a court held that either misrepresentation or mistake could apply where a seller misrepresented that an entire plot of land was buildable when a portion of it had been designated as protected wetlands. ${ }^{158}$ The court observed that the two theories frequently apply to the same situation..$^{159}$ This, of course, is the case because any information that substantially contributes to a contracting party's decision for purposes of the misrepresentation defense is also likely to regard an important matter for purposes of the mistake defense. In the same vein, the Ninth Circuit, in Reliance Finance Corporation v. Miller, wrote that California law created a higher bar of materiality for mistake than for misrepresentation, but it then conceded that mistake and misrepresentation "may really encompass the same facts and concerns, although articulated in different terms." 160 The court concluded, as this Article concludes, that "it is all too easy to confuse these two distinct doctrines ... ."161 Indeed, it is difficult to conceive of a fact pattern that meets the standard of inducement in misrepresentation but not those of basic assumption and materiality in mistake.

154. See id. § 164 .

155. See Renner v. Kehl, 722 P.2d 262, 265 (Ariz. 1986) (en banc decision) (finding that the parties' mistaken beliefs that adequate water supplies existed beneath a parcel of land was a mistake of fact and produced a failure of consideration.); Kim, supra note 2, at 485 (explaining that the critical issue regarding basic assumption defenses is the parties' contractual intent); Val D. Ricks, American Mutual Mistake: Half-Civilian Mongrel, Consideration Reincarnate, 58 LA. L.REV. 663, 738 (1998) (likening mistake to failure of consideration).

156. RESTATEMENT (SECOND) OF CONTRACTS $\S \S 152,153$ (1981).

157. See Shore Builders Inc. v. Dogwood, 616 F. Supp. 1004, 1017 (D. Del. 1985) (stating that materiality is a higher bar for mistake than for misrepresentation, but the facts of the case conceivably allowed the use of either theory).

158. See id.

159. Id. at 1012 .

160. 557 F.2d 674, 680 (9th Cir. 1977).

161. Id. 
When a misrepresentation regards performance itself, the outcome should be the same in cases of misrepresentation and mistake, so long as the mistake is material. For example, assume that David sells a vintage El Camino to Jeff. He falsely represents, either innocently or fraudulently, that the car has all of its original parts. Jeff, a stickler for authenticity, is influenced by David's representation. As in the example above, the inducement prong of Jeff's misrepresentation defense is satisfied. The authenticity of the car was a basic assumption upon which the contract was based, and the materiality prong of the mistake test is also clearly satisfied. Jeff expected to give a sum certain in exchange for a wholly authentic El Camino. His performance and David's return performance are moved out of equilibrium by the failure of David's representation.

When the misrepresentation regards something external to the parties' performances, the comparison is more complicated. For example, assume that Kenworthey will sell real property to Kate. Kenworthey falsely represents, either innocently or fraudulently, that the area is heavily trafficked and safe. Kate, who intends to open a dance studio on the premises, is influenced by Kenworthey's representation. Through the lens of the misrepresentation defense, she was induced to enter the bargain by Kenworthey's false assertion. So is misrepresentation's inducement requirement adequately mirrored by the prongs of mistake? The answer is yes and probably. Public density and safety are factors external to the parties' performances. They are basic assumptions upon which the parties based their bargain, so Kate's mistake defense will clear the first hurdle. But regardless of the relative safety of the property, Kate's and Kenworthey's performances remain the same: Kate will pay the same price and Kenworthey will deliver the same property, whether it is bustling and safe or not. In other words, the materiality requirement of the mistake defense is likely met, but a court may quibble over whether the difference is one of mere value. ${ }^{162}$ It is here that courts of yesterday could have more easily distinguished between inducement in misrepresentation and materiality in mistake. Modern courts, however, typically perceive a change in value as indicative of a real difference in what the adversely affected party bargained for versus what she received, which leaves very little room in which to distinguish inducement from materiality. ${ }^{163}$

That the tests are satisfied by similar facts is also evident from the resulting remedy arising from each defense. In Liberto $v$. Bensinger, a court held that the misrepresentation defense sets a high bar for materiality because rescission is an "extreme remedy."

162. See Sherwood v. Walker, 33 N.W. 919,923 (Mich. 1887) (holding that the seller of a cow who thought the animal was barren could rescind contract upon discovery that she could calve because the cow's fertility was not an issue of value but was the very essence of the contract's subject matter).

163. See Lenawee Cnty. Bd. of Health v. Messerly, 331 N.W.2d 203, 209 (1982) ("Often, a mistake relates to an underlying factual assumption which, when discovered, directly affects value, but simultaneously and materially affects the essence of the contractual consideration.").

164. No. Civ.A. 1411-K, 1999 WL 1313662, at *5 (Del. Ch. Dec. 28, 1999). 
remedy that is available for both mistake and misrepresentation. Why, then, would courts purport to require a greater level of material importance for mistake than for misrepresentation? Perhaps the answer is the desire to punish or deter culpable behavior. Alternatively, perhaps the answer is simply that this is a mere incantation and that the bar is no higher in one doctrine than in the other. I argue that the latter assertion is correct. The alleged difference is minor at best and cannot be used to justify the retention of misrepresentation as a separate doctrine from mistake.

\section{Fraudulence or Materiality}

To be an actionable defense, a mistake must meet a threshold of materiality ${ }^{165}$ in that the injured party's false belief must have a material effect on the agreed upon exchange of performances. ${ }^{166}$ Materiality, in this instance, means that the mistake has created a serious imbalance in the exchange of performances that is unfair to the adversely affected party. ${ }^{167}$ Misrepresentation, on the other hand, is actionable under the $\mathrm{Re}$ statement when it is either material or fraudulent. ${ }^{168}$ Mistake and nonfraudulent misrepresentation, then, impose a facial requirement for materiality while fraudulent misrepresentation does not. ${ }^{169}$ Initially, this appears to be a significant difference between mistake and fraudulent misrepresentation because in theory, a fraudulent misrepresentation may be actionable even if it is not material, whereas a mistake is actionable only if it is material. If the distinction truly exists, it is an important one. Allowing an adversely affected party relief where there is fraud but not materiality would further underscore misrepresentation's district normative stance. Fraud, no matter how inconsequential, could make a deal voidable, making it impossible to view fraudulent misrepresentation as nothing more than a remedy for failed consent or consideration. By refusing to consider the materiality of a misrepresentation in cases of fraud, courts would shift focus from the result of failed bargaining to the relative culpability of the parties. This is a clear demonstration of the doctrine's normative position: those who engage in fraud should be deterred or punished. Mistake, on the other hand, lacks this strength of normative focus.

Is this a reason to retain separate defenses of mistake and misrepresentation? The answer is no. Misrepresentation's normative stance is all bark and no bite under current law. Although commentators claim that a misrepresentation can be both fraudulent and nonmaterial, cases like

\footnotetext{
165. RESTATEMENT (SECOND) OF CONTRACTS $§ \S 152,153$ (1981).

166. Id. $\$ \$ 152,153$.

167. Id. $\$ 152 \mathrm{cmt}$. c

168. Id. § 164 .

169. Id. $\$ 162 \mathrm{cmt}$. c ("A fraudulent misrepresentation need not be material in order to entitle the recipient to relief ....").
} 
this are rare in practice ${ }^{170}$ and are also unlikely to succeed in most jurisdictions. It is highly unlikely that such a misrepresentation would ever be actionable because the fraud defense typically requires intent to induce and actual inducement. ${ }^{171}$ Unless an adversely affected party was induced by the fraudulent representation, a court generally cannot afford relief to her. ${ }^{172}$ This is because the test for inducement is nearly identical to the test for materiality of a misrepresentation. ${ }^{173}$ A misrepresentation by which the adversely affected party is induced, i.e., upon which he relies when entering into the bargain, must also have some significance to that party. It is, therefore, nearly impossible to describe a fraudulent misrepresentation that is not also material. In fact, many states impose a materiality requirement in cases of fraudulent misrepresentation. ${ }^{174}$ The lack of an explicit materiality requirement in some iterations of fraudulent misrepresentation should not present an obstacle to the adoption of a combined defense.

At this juncture, it is useful to compare the meaning of materiality for purposes of mistake and misrepresentation. A mistake is material when it significantly alters the allocation of benefits and burdens in the bargain. ${ }^{175}$ The test is seemingly objective: a court may declare a contract void if the result is so imbalanced that enforcement of the deal would be unjust. ${ }^{176}$ Materiality in misrepresentation is different. Instead of focusing on the outcome as mistake does, misrepresentation looks to the maker's intent. ${ }^{177}$ According to the Restatement, "[a] misrepresentation is material if it would be likely to induce a reasonable person to manifest his assent, or if the maker knows that it would be likely to induce the recipient to do so." ${ }^{178}$ From a pragmatic standpoint, the difference between the two tests is more semantic than it is real. Any misrepresentation that is likely to induce a party to enter a bargain is also likely to refer to benefits and burdens that are important to the adversely affected party. Here again, the iterations of the defenses highlight a fundamental distinction between them. Mistake focuses on the adverse effect of a mistaken belief, whereas misrepresentation is far more concerned with the vector of that harm. This reflects both different origins of the defenses at law and at equity and differing normative motivations for the defenses. These distinctions should be addressed by any attempt to combine the two.

170. See FARNSWORTH ON CONTRACTS $\$ 4.12$, at 459 (2d ed. 1998) (Cases granting rescission for non-material fraud are "difficult to find").

171. Id. at 458 (stating that a misrepresentation is not fraudulent unless the maker intended to induce the assent of his counterparty); RESTATEMENT (SECOND) OF CONTRACTS $\$ \$ 162,164$ (1981).

172. Id. $\$ 164$. No legal effect flows from either a nonfraudulent or a fraudulent misrepresentation unless it induces action by the recipient that is, unless he manifests his assent to the contract in reliance on it. Id. $\$ 164 \mathrm{cmt}$. b.

173. See id. $\$ 167 \mathrm{cmt}$. b.

174. For the obligatory string citation, see supra note 94 .

175. RESTATEMENT (SECOND) OF CONTRACTS $\$ 152 \mathrm{cmt}$. c (1981).

176. Id.

177. Id. $\$ 162(2)$.

178. Id. 
In summary, although mistake and misrepresentation differ facially because the former requires materiality while the latter does not require materiality in cases of fraud, the two doctrines are largely the same. Fraudulent misrepresentations are likely to also be material because the maker must have intended them to induce assent, and they must have actually induced assent. Thus, there is no reason to maintain separate legal tests for voidability as a result of mistake and misrepresentation.

\section{Justified Reliance and Risk Allocation}

Both mistake and misrepresentation deny relief to adversely affected parties in certain situations even if all other requirements are satisfied. In cases of mistake, an adversely affected party cannot prevail if he bears the risk of the mistake. ${ }^{179}$ In misrepresentation, he cannot prevail if his reliance on the misrepresentation was not justified. ${ }^{180}$ Once again, although the tests are facially different, they do not present a barrier to combining mistake and misrepresentation. Risk allocation under mistake is actually much broader than justified reliance and can be made to comfortably encompass it; however, doing so may unnecessarily narrow the range of cases to which a combined defense would apply.

Risk may be allocated in one of three ways in cases of mistake: the adversely affected party expressly assumes the risk as part of the deal; he enters the deal and is conscious of his own lack of knowledge; or the court allocates risk to him because it is reasonable to do so. ${ }^{181}$ Each of these has a corollary in the justified reliance portion of the misrepresentation defense, although they are not always formally iterated as a part of the test.

\section{Justified Reliance Is Impossible in the Face of Conscious Ignorance}

In cases of mistake, a party acts with conscious ignorance when he treats his limited knowledge as sufficient to enter into an agreement. ${ }^{182}$ One court has described it as "a 'conscious present want of knowledge of facts' which a party has manifestly concluded will not influence the decision to contract."183 Another court has characterized it as an "attitude of indifference." 184 The rule requires a party to ascertain the facts for himself by reasonable diligence. ${ }^{185}$ For instance, where a buyer is aware that

\footnotetext{
179. Id. $\$ \$ 152,153$.

180. Id. $\$ 164(1)$.

181. Id. $\$ 154$.

182. See Horney v. Westfield Gage Co., 77 Fed. App'x. 24, 34 (1st Cir. 2003) (holding that a settlement agreement was not invalid where the party relied on the statement of another that the agreement was acceptable instead of reading it himself).

183. Bentley v. Slavik, 663 F. Supp. 736, 742 (S.D. Ill. 1987) (quoting Harley v. Magnolia Petroleum Co., 37 N.E.2d 760, 765 (1941)).

184. S. Nat'l Bank of Hous. v. Crateo, Inc., 458 F.2d 688, 693 (5th Cir. 1972).

185. See Armco, Inc. v. S. Rock, Inc., 696 F.2d 410, 412-13 (5th Cir. 1983) (finding that a party could not void contract where it assumed responsibility for repairing a damaged sewer pipe without
} 
a seller is uncertain about the location of a boundary line but does not hire a surveyor to ascertain it, relief for the mistake is generally unavailable. ${ }^{186}$ In such a case, the buyer is aware that additional information is available but does not seek it. If the buyer is rational, she will bargain for a return on the assumed risk, asking for either a concession or additional consideration to account for the possibility that the unknown information might be adverse. Alternatively, she may conclude that additional investigation would be more costly than fruition of the risk. In either case, a court should respect the bargain of the parties because the adversely affected party has been compensated for her loss on her own terms. ${ }^{187}$

The law of misrepresentation is similar, though not identical. A party's failure to discover the truth, even if the failure is negligent, will not bar relief unless it amounts to a breach of good faith and fair dealing. ${ }^{188}$ This does not mean, however, that one party can rely on another's representation while disregarding all else. ${ }^{189}$ At the very least, a "cursory examination" is required. ${ }^{190}$ The presence of a misrepresentation does not vitiate a party's responsibility to be cognizant of the facts and circumstances of a transaction. Instead, a party "is expected to use his senses and not rely blindly on the maker's assertion." 191

While the justified reliance test is facially different from mistake's requirement of reasonable diligence, ${ }^{192}$ the two may be very similar in practice. As discussed above, courts assessing the justified reliance prong also may require diligence from the adversely affected party. ${ }^{193}$ Otherwise stated, courts may prohibit rescission where the adversely affected

first investigating who was liable for the damage) (citing Hunt v. Davis, 45 So. 2d 350, 352 (Miss. 1950)).

186. But see Bailey v. Ewing, 671 P.2d 1099, 639-40 (Idaho Ct. App. 1983). Interestingly, this case allowed relief because although both parties were aware of their uncertainty about the parcel's boundary, neither could have anticipated that it would run directly through the house. The court therefore held that neither party had consciously assumed the risk. See also 7 PERILLO, supra note 105, § 28.28, at 124 (stating that a seller of land who warrants title or quality of land cannot escape warranty by claiming ignorance of defects since presence of warranty is proof that the seller was aware of and explicitly assumed the risk).

187. But what if the buyer is not rational? In this case, a court should still enforce the parties' bargain because modern contract law focuses on objective, rather than subjective, manifestations of intent to determine the meaning of the bargain. See, e.g., Wood v. Lucy, Lady Duff-Gordon, 118 N.E. 214, 214-15 (N.Y. 1917). An objective observer considering a transaction conducted in conscious ignorance by one of the parties could observe the act but could not observe whether that party's inner thoughts were rational or irrational. Since courts are loathe to inquire as to the adequacy of consideration, they should also assume that a party acting in conscious ignorance has demanded adequate consideration for the assumption of risk arising from the undiscovered information. See, e.g., Browning v. Johnson, 422 P.2d 314, 315-16 (Wash. 1967) (stating that a court will not inquire into the adequacy of consideration).

188. See Woodling v. Garrett Corp., 813 F.2d 543, 553 (2d Cir. 1987) (finding that a party's reliance on the opposing council's statements was reasonable and did not bar recovery, particularly in light of the opposing council's ethical duty to deal honestly); RESTATEMENT (SECOND) OF CONTRACTS $\S 172 \mathrm{cmt}$. a (1981).

189. See RESTATEMENT (SECOND) OF CONTRACTS $\$ 172 \mathrm{cmt}$ a (1981).

190. Id. $\$ 172 \mathrm{cmt}$. b.

191. Id.

192. No pun intended .... .

193. See supra note 110 and accompanying text. 
party reasonably should have been aware of the misrepresentation. This is one semantic twist away from holding that a party is not entitled to rescission where she contracted in conscious ignorance of the truth of her counterparty's representations. For instance, in 1934, the high court of Florida held that a party lacks the right to rely on another's misrepresentation if "the transaction was entered into upon the express understanding of both parties that a material fact might exist of which one of them was ignorant ...."194 A more modern example is Metavante Corp. $v$. Emigrant Savings Bank, where the Seventh Circuit required diligence in a deal between two sophisticated parties. ${ }^{195}$ Metavante represented that its direct banking system was an integrated and proven model that could handle a large volume of transactions ${ }^{196}$ and in a countersuit, Emigrant sued to avoid an agreement to use the system. ${ }^{197}$ The truth, according to Emigrant, was that Metavante had only one client whom it serviced through a subcontractor. ${ }^{198}$ The district court held that Emigrant could not avoid its contractual obligation because it had failed to investigate the facts, ${ }^{199}$ and the Seventh Circuit affirmed this holding. ${ }^{200}$ Because the parties were both sophisticated businesses that had negotiated the contract over a period of several months, the court found that it was unreasonable for Emigrant to rely solely on Metavante's statements. ${ }^{201}$ The Seventh Circuit added that a party "may not close his eyes to what is obviously discoverable by him."202 In other words, Emigrant should have been aware of the risk that Metavante had misrepresented facts, but it entered into the contract without confirming them. As a result, it could not avoid the deal. ${ }^{203}$

Other courts have required diligence in misrepresentation cases. In Resolution Trust Corp. v. District of Columbia, a court held that the District could not avoid a contract where an alleged misrepresentation was easily discoverable by reading complex documents in the District's possession. ${ }^{204}$ In Liberto $v$. Bensinger, a sophisticated buyer could not rely on the seller's conclusion that zoning laws would not interfere with application for a building permit. ${ }^{205}$ Instead, the buyer should have hired an attorney to investigate. ${ }^{206}$ In these cases, "[t] he extent to which the representee must verify the truth of the representation, if he or she must do so at all, depends upon the circumstances of the case." 207 Where facts are

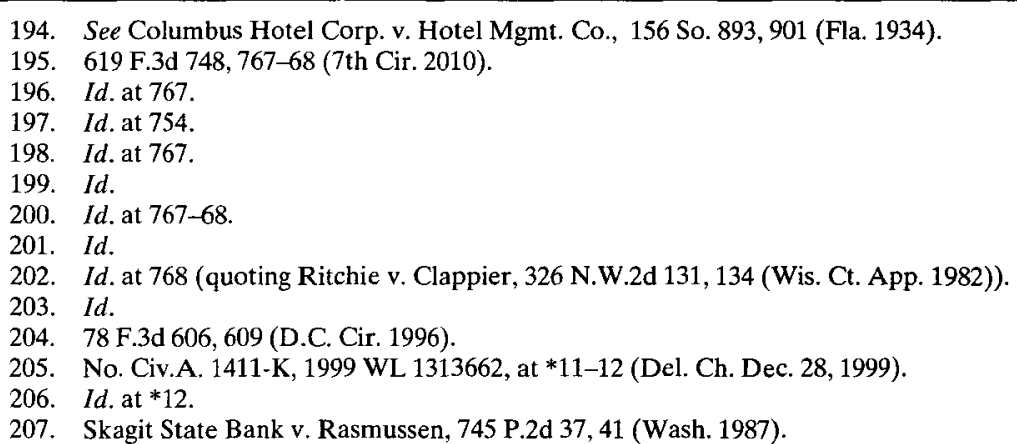


easily discoverable, recovery is barred. ${ }^{208}$ Indeed, the Washington Supreme Court has gone so far as to create a contributory negligence defense in contract misrepresentation cases to account for the adversely affected party's own fault. ${ }^{209}$ Finally, at least one commentator has noted that the conscious ignorance prong of the mistake test would be eviscerated if a party could avoid it by relying on the questionable representations of another. ${ }^{210}$ Courts clearly expect a reasonable level of diligence by the adversely affected party in many cases of misrepresentation, and these fact patterns hint at mistake's bar against rescission in cases where the adversely affected party acted with conscious ignorance.

Mistake initially seems to place a heavier burden on the adversely affected party by requiring more than cursory diligence and by assuming that when a party has acted in conscious ignorance, she has bargained for a return on her assumed risk. But as the cases indicate, misrepresentation can be just as demanding. Although the misrepresentation defense purports to require only a cursory investigation to discover the obvious, courts have asked for more, particularly where the parties are sophisticated. Where the adversely affected party has conducted an inadequate investigation, an economic analysis similar to that in mistake cases may apply. In the Metavante case, for example, the adversely affected party could have demanded a return for the risk that its counterparty was misrepresenting facts. Alternatively, it rationally could have calculated $e x$ ante that the cost of its counterparty's possible misrepresentation was less than the cost of investigation. Or it simply could have proceeded with flagrant disregard for the potential risk, finding it so inconsequential as not to merit consideration. In any of these cases, the pragmatic effect is the same as if the adversely affected party had been presented with the fact of its own insufficient knowledge in advance of the bargain. In the end, both mistake and misrepresentation seem to ask whether the adversely affected party is presumed to have bargained with awareness of his lack of knowledge. Thus, the facial difference between the two once again fails to justify retention of two sets of legal rules where one would suffice.

\section{Justified Reliance and Express Allocation of Risk}

Acting in conscious ignorance is but one way in which parties may assume the risk of mistake in a bargain. A second means of assuming risk is express allocation by agreement. For instance, a party who agrees to buy a car "as is" has accepted the risk that the car will have a defect. ${ }^{211}$

208. See RESTATEMENT (SECOND) OF CONTRACTS $§ 172$ (1981).

209. See Skagit State Bank, 745 P.2d at 42.

210. See 7-28 CoRbin ON CONTRACTS $\$ 28.28$ (criticizing City Life Dev., Inc. v. Praxus Grp., Inc., No. 88221, 2007 WL 1290169 (Ohio Ct. App. 2007)).

211. See, e.g., Lenawee Cnty. Bd. of Health v. Messerly, 331 N.W.2d 203, 210-11 (Mich. 1982) (finding that a purchaser could not avoid a contract for the sale of real estate on the basis of a faulty septic system because the contract provided that the purchaser had agreed to accept the property "in its present condition."); see also U.C.C. $\$ 2-316(3)$ (a) (2007) ("[U]nless the circumstances indicate oth- 
As a return for that risk, a rational buyer will demand a lower price or additional consideration from the seller. Because the buyer's assumption of risk has been the subject of bargaining by the parties, courts will not allow an adversely affected party to avoid the deal if the allocated risk comes to fruition. ${ }^{212}$

Although the misrepresentation defense has no exact corollary to mistake's express assumption of risk, a number of courts have barred use of the misrepresentation defense on the basis of express language in the parties' agreement. ${ }^{213}$ Once again, the source of these decisions is the justified reliance prong of the defense..$^{214}$ Where the alleged maker of a misrepresentation has disclaimed his assertion, or where an adversely affected party has explicitly waived his right to rely on the maker's assertion, a court will not allow the adversely affected party to avoid a contract on the basis of misrepresentation. ${ }^{215}$ For example, in McCartin $v$. Westlake, a Massachusetts appellate court looked at the language of a franchise agreement to support its holding that franchisees could not avoid a contract on the basis of the franchisor's alleged misrepresentation about plans for the growth of and assistance from the company. ${ }^{216}$ The parties had engaged in more than three months of negotiation through counsel prior to reaching an agreement. ${ }^{217}$ The resulting written documents included a disclosure statement cautioning the franchisees that they should fully understand the provisions of the franchise agreement before signing it. ${ }^{218}$ The agreement itself provided that the franchise was a speculative venture and that the franchisees agreed to be bound only after conducting an independent investigation. ${ }^{219}$ The court found that the franchisees could not justifiably rely on the franchisor's representations in the face of such explicit disclaimer language. ${ }^{220}$ The same analysis applies when a party contractually agrees not to assert the defense. ${ }^{221}$ For instance, the Third Circuit in MBIA Insurance Corp. v. Royal Indemnity Co. refused to void a contract where the adversely affected party had agreed to such a term..$^{222}$

erwise, all implied warranties are excluded by expressions like 'as is,' 'with all faults' or other language that in common understanding calls the buyer's attention to the exclusion of warranties and makes plain that there is no implied warranty.").

212. See Messerly, 331 N.W.2d at 210-11; RESTATEMENT (SECOND) OF CONTRACTS $\$ 154$ (1981).

213. See, e.g., MBIA Ins. Corp. v. Royal Indem. Co., 426 F.3d 204, 220 (3d. Cir. 2005) (finding that a defense is unavailable where the adversely affected party contractually waived the right to raise it) Columbus Hotel Corp. v. Hotel Mgmt. Co., 156 So. 893, 901 (Fla. 1934) (stating that an adversely affected party cannot rely on a misrepresentation when "a party has expressly said that he would not be bound by his representations ..."); McCartin v. Westlake, 630 N.E.2d 283, 287-91 (Mass. App. Ct. 1994) (holding that the presence of disclaimer language defeated a misrepresentation defense.

214. See supra note 213.

215. See id.

216. See 630 N.E. $2 d$ at $289-98$

217. Id. at 289 .

218. Id. at $287-88$.

219. Id. at 288 .

220. Id. at 290; see also Columbus Hotel Corp. v. Hotel Mgmt. Co., 156 So. 893, 901 (Fla. 1934)

221. See MBIA Ins. Corp. v. Royal Indem. Co., 426 F.3d 204, 220 (3d. Cir. 2005).

222. Id. 
It is possible to recast these holdings in terms of the mistake defense. Where the maker of a misrepresentation has disclaimed it, the adversely affected party is mistaken about the truth of the representation. This mistake cannot be the basis of a defense, however, because the adversely affected party has assumed the risk that the counterparty misspoke. Here, assumption of the risk takes the form of conscious ignorance. The adversely affected party entered into the agreement even though he was given notice, in the form of a disclaimer in the agreement, that his counterparty might have made a misrepresentation. Barring the defense also makes sense from an economic perspective as well. If the adversely affected party is a rational actor, he will have bargained for concessions in return for the disclaimer language, garnering return for his risk by either paying a lower price or receiving additional consideration. The same is true of an adversely affected party's explicit waiver of the right to raise a misrepresentation defense. As a result, courts have not permitted parties to raise the defense in such circumstances. ${ }^{223}$

In summary, while the misrepresentation defense does not include an express corollary to the bar created by explicit assumption of risk in mistake cases, the justified reliance prong of misrepresentation produces a similar result in most cases. When the adversely affected party has notice of a potential for misrepresentation from a waiver or disclaimer language in a contract, then a court should find that reliance on the representation is not justified.

\section{Justified Reliance and Allocation of Risk by Courts}

A third means of risk allocation in mistake cases is allocation by a court. Here, too, mistake and misrepresentation overlap to a great extent. In cases of mistake, if parties have neither allocated the risk of mistake by agreement nor assented with conscious ignorance, a court may allocate the risk of mistake using a reasonable basis. ${ }^{224}$ This catchall provision encompasses cases where one party had a better opportunity to discover or bargain against the mistake as well as cases where a party somehow contributed to the mistake either through lack of care or failure to follow trade custom. ${ }^{225}$ Like the analysis of justified reliance in misrepresentation cases, allocation of risk by courts in mistake cases is highly fact-bound and tends to focus on which party is more at fault, even when there is no particular fault at issue or when both parties are at fault.

In Wasser \& Winters Co. v. Ritchie Bros. Auctioneers, Inc., Wasser, for example, a secured creditor, released its interest in a debtor's assets that were then sold by Ritchie, an auction company. ${ }^{226}$ During allocation

223. See MBIA, 426 F.3d at 220; McCartin, 640 N.E.2d at 290; Columbus Hotel Corp., 156 So. at 901.

224. RESTATEMENT (SECOND) OF CONTRACTS $§ 154$ (c) (1981).

225. See supra Part I.D.

226. 185 P.3d 73, 78-81 (Ala. 2008). 
of the auction proceeds, Wasser was upstaged by tax lien holders that the debtor had not identified prior to the sale. The Alaska Supreme Court allocated the risk of the undisclosed tax liens to Wasser despite Ritchie's representation that there were no tax liens on the property. ${ }^{227}$ The court could not allocate risk to Wasser on the basis of conscious ignorance because Ritchie's misrepresentation prevented Wasser from realizing its own ignorance, ${ }^{228}$ instead, the court allocated risk of the liens' existence to Wasser because doing so was reasonable in light of the facts and circumstances. ${ }^{229}$ The court noted Wasser's sophistication: ${ }^{230}$ it had conducted lien searches prior to releasing its interest in the debtor's property and had not discovered the undisclosed liens. ${ }^{231}$ Furthermore, Wasser had far more at stake than Ritchie because the auctioneer would receive a fixed amount regardless of how the net proceeds from the sale were distributed..$^{232}$ The court seems to suggest that Wasser should not have relied on Ritchie, which had nothing to lose. ${ }^{233}$ "At the very least," the court wrote, "Wasser could have asked Thomas [the debtor] whether liens existed." ${ }^{234}$ The court added that assigning the risk of loss to Ritchie made no sense because it would expose Ritchie to liabilities greatly in excess of its possible profit and "far out of proportion to those Wasser faced whether or not it was fully informed." 235

Interestingly, the Wasser court contemplated the possibility of allocating risk to Ritchie on the basis of its misrepresentation that no other liens existed. ${ }^{236}$ But the court noted that the stakes were higher for Wasser than for Ritchie, that the representation came only one day prior to the auction, and that both parties were sophisticated enough to know that tax liens might reduce the net auction proceeds. ${ }^{237}$ Ultimately declining to penalize Ritchie for an unintentional misstatement, the court allocated the risk to Wasser. The court essentially held that Wasser was not justified in relying on Ritchie's misrepresentation; therefore, justified reliance could not be used as a basis for allocating risk of mistake to Ritchie. ${ }^{238}$ Here the two tests are inextricably intertwined, with justified reliance doing double duty in mistake and misrepresentation. It is possible to infer from the court's opinion that if Wasser had been justified in relying on Richie's misrepresentation, then the court would have allocated risk of the mistake to Richie. The language of the case demonstrates just how similar allocation of risk and justified reliance are and suggests that

227. Id.

228. Id. at 79 .

229. Id. at $79-81$.

230. Id. at 79 .

231. Id.

232. Id. at 80 .

233. Id.

234. Id. at 79.

235. Id. at 80 .

236. Id.

237. Id.

238. See id. 
although they are semantically different, they are substantively very similar.

\section{Risk of Mistake, Though Similar, Is Broader Than Justified Reliance}

Despite similarities between assumption of the risk of mistake and justified reliance on a misrepresentation, the two are not coextensive. Assumption of the risk is a broader concept than justified reliance, and in theory, the defense of mistake is more difficult to assert. ${ }^{239}$ While it is arguably the case that justified reliance on a misrepresentation is fully subsumed by mistake's conscious ignorance and assignment of risk by courts, the reverse is not true. For instance, a purchaser whose contract specifies that an item is sold "as is" has agreed to defects, obvious, or hidden, as a part of the bargain. Parties who explicitly assume risk in this way are presumed to have bargained for concessions in return, so it cannot be said that there is a failure of consent or consideration when the bargained-for risk materializes. Accordingly, courts will not declare these contracts voidable.

The Restatement formulation of misrepresentation, by contrast, contains no corollary to mistake's prohibition on explicit assumption of risk. ${ }^{240}$ In the above example, when a purchaser buys goods "as is," the misrepresentation defense may apply as long as its other prongs are met. Here, misrepresentation reaches a different result from mistake and on different normative grounds. This disparity must be accounted for in a combined defense, and there are three possible ways to address it. The first possibility is to apply the bar on assumption of risk to misconceptions arising from both mistake and misrepresentation. This approach is overly broad because it would punish those who, as a result of a misrepresentation, misjudge the magnitude of a particular risk. The second possibility is to apply it to neither. This approach is too narrow because it would permit adversely affected parties to avoid a deal even in cases where they bargained for concessions in exchange for their assumption of the risk. Finally, as discussed below, the third and best choice is to refine the assumption of risk analysis by asking courts to interpret the extent to which a party has assumed risk in light of a misrepresentation. This approach, which closely considers the specific circumstances of each deal, best protects the parties' expectation interests in the deal..$^{241}$

239. See supra Part III.B; see also Reliance Fin. Corp. v. Miller, 557 F.2d 674, 680 (9th Cir. 1977) (stating that the defenses of mistake and misrepresentation apply to common fact patterns even though California law purports to set a higher bar for mistake); Shore Builders v. Dogwood, 616 F. Supp. 1004, 1017 (D. Del. 1985) (stating that there is a higher standard of materiality for mistake than for misrepresentation, but the facts of case allowed the use of either theory).

240. RESTATEMENT (SECOND) OF CONTRACTS ch.7 (1981) (describing the misrepresentation defense).

241. For a thorough discussion of this conclusion, see infra Part V.C. 


\section{E. Comparison of Remedies: Fraud's Failed Attempt to Go the Extra Mile}

As stated in the Restatement, the typical remedies available in successful defenses of mistake and misrepresentation are largely coextensive. In most cases, an adversely affected party is entitled to rescission, and if he has conferred a benefit upon his counterparty, he is also entitled to restitution. ${ }^{242} \mathrm{~A}$ court also may grant other relief "as justice requires, including protection of the parties' reliance interests."243 It appears that courts are charged with restoring the adversely affected party to his pre-contract position to the extent possible, and either defense will produce the same result at this level of analysis.

A closer look at restitution produces a more nuanced view. As a remedy in contract law, restitution is meant to restore to its recipient "any benefit that he has conferred on the other party." ${ }^{244}$ However, as a doctrine with roots in equity, restitution is also deeply concerned with deservingness and unjust enrichment. As a result, the scope of the restitutionary remedy available in fraud defenses is larger than that available in cases of innocent misrepresentation and mistake. ${ }^{245}$ In all cases, the recipient of a benefit must return it, but the Restatement commentary explains that "[u]ncertainties in measuring the benefit, however, are more likely to be resolved in favor of the party seeking restitution if the other party engaged in misconduct, as in cases of fraudulent misrepresentation, duress or undue influence. ${ }^{246}$

Restitution's focus on culpability manifests itself more pointedly as a requirement that the maker of a fraudulent misrepresentation disgorge not only the benefit she received from the adversely affected party, but also any profits that she made as a result of the failed transaction. ${ }^{247}$ In

242. 2 GEORGE E. PALMER, THE LAW OF RestTution $\$ 12.6$, at 583 (1978) ("When relief is given for mistake in basic assumption, this normally means that the contract is rescinded."); RESTATEMENT (SECOND) OF CONTRACTS $\$ 158$ (1981) (stating that parties in a mistake case "may have a claim for relief including restitution ..."); id. $\$ 376$ (stating that a party who successfully pleads mistake or misrepresentation is "entitled to restitution for any benefit that he has conferred on the other party by way of part performance or reliance"). Here, "restitution" refers to a remedy in contract law rather than a separate cause of action for unjust enrichment. See IAN AYRES \& RICHARD E. SPEIDEL, STUDIES IN CONTRACT LAW 109 (7th ed. 2008).

243. See RESTATEMENT (SECOND) OF CONTRACTS § 158(2) (1981) (describing other forms of relief in mistake cases); 7 PERILLO, supra note $105, \$ 28.23$, at 100 ("In many cases, restitutionary recovery [for fraud] has included reliance damages."). For instance, reformation is also available in mistake cases where the written agreement does not embody the bargain reached by the parties. See RESTATEMENT (SECOND) OF CONTRACTS $\$ 155$ (1981).

244. RESTATEMENT (SECOND) OF CONTRACTS $\$ 344$ (c) (1981).

245. See id. $\S 376 \mathrm{cmt}$. a, illus. 5 (requiring the maker of a fraudulent misrepresentation to disgorge both the conferred benefit and the profits).

246. Id. $\$ 376 \mathrm{cmt}$. a.

247. See RESTATEMENT (FIRST) OF RESTITUTION $\$ 157 \mathrm{cmt}$. d (1937) ("If the recipient obtained land by fraud, duress, or other consciously tortious means, the claimant is entitled, at his election, to receive its income or the reasonable value of its use."); id. $\$ 160 \mathrm{cmt}$. d ("[W]here the defendant makes a profit through the consciously wrongful disposition of the plaintiff's property, he can be compelled to surrender the profit to the plaintiff and not merely to restore to the plaintiff his property or its value."). 
some cases, courts conceive of restitution for fraud as the imposition of a constructive trust; the maker of the misrepresentation is deemed to hold benefits conferred by the adversely affected party in trust for her, so that any increase in value or any profits accrued in the maker's hands belong to the adversely affected party. ${ }^{248}$ The disgorgement of profits does not seem to be popular, however, in common law contract cases and instead appears mainly in cases involving the transfer of real estate as a result of fraud. ${ }^{249}$

The disgorgement of profits in successful invocations of the fraud defense presents a line of demarcation between mistake and misrepresentation, and it is reflective of the more fundamental normative differences between the two defenses. Once again, mistake focuses on remedying the unfavorable result of a bad bargain, whereas fraud focuses on the culpability of the party who caused the unfavorable result. It is here, in the remedy available for fraud, that one would expect to see the fullest expression of that normative distinction. And it is here that the fraud defense is most disappointing. While disgorgement of profits is undoubtedly harsher than simple restitution, it is not punitive in nature and therefore does little to deter or punish nonnormative behavior. At best, it removes an incentive for such behavior by refusing to allow the maker of a fraudulent misrepresentation to emerge from the transaction in a more favorable financial position. As this incentive is never present in cases of innocent misrepresentation or mistake where the nonadversely affected party's behavior was inadvertent, remedial disgorgement of profit simply places fraud cases on par with cases where scienter is never present. This is insufficient from a normative perspective. If a potential nonnormative actor is subject only to contract defenses, and not to tort liability, she rationally will choose to gamble on fraud, even in the face of disgorgement of profits. If she is caught, she will be returned to her pre-fraud position by a court. If she is not caught, she will be better off. Consequently, she faces only a positive return on her risk. In this regard, the remedies available for a successful invocation of the fraud defense fail to accomplish the normative goals of deterrence and punishment that justify of its

248. See Lang v. Giraudo, 40 N.E.2d 707, 708, 711 (Mass. 1942) (explaining that a woman who had bought property using a fraudulent assertion that she would soon pay cash from a large fortune was a constructive trustee and as such was required to remit any profits earned from the property); Brooks $\mathrm{v}$. Conston, 72 A.2d 75, 78 ( $\mathrm{Pa}$. 1950) (referring to a chain of stores sold to the defendant as a result of the defendant's fraudulent misrepresentations, the court wrote that "[p]laintiffs are entitled to the fruits of the use of property which, in equity, continued to be theirs throughout the period of the defendants' operation"); see also Nickel v. Bank of Am. Nat. Trust and Sav., 290 F.3d 1134, 1138 (9th Cir. 2002) ("The elementary rule of restitution [for fraud] is that if you take my money and make money with it, your profit belongs to me."); 7-28 CORBIN ON CONTRACTS $\S 28.23$.

249. RESTATEMENT (SECOND) OF CONTRACTS $\$ 376 \mathrm{cmt}$. a, illus. 5 (1981), describes such a case: A fraudulently induces $B$ to make a contract to sell a tract of land for $\$ 100,000$. After $B$ has conveyed the land and $A$ has paid the price, $A$ farms the land at a net profit of $\$ 10,000$. B then discovers the fraud, disaffirms the contract for misrepresentation, tenders back the $\$ 100,000$, and sues $A$ for specific restitution plus the $\$ 10,000$ profit that $\mathbf{A}$ made by farming the land. B can recover the land and $\$ 10,000$ in restitution from $\mathrm{A}$.

For more examples, see supra note 249. 
separation from the defense of mistake. A combined defense should either abandon those goals or more effectively address them.

\section{A COMBINED DEFENSE}

\section{A. A Combined Defense Is Better Than Separate Defenses}

There are at least two strong reasons to prefer a combined defense of misconception to separate defenses of mistake and misrepresentation. The first reason is simple and pragmatic. One party's misrepresentation, if believed, necessarily causes another's mistake that results in a significant area of overlap between the two defenses. ${ }^{250}$ Practically speaking, most (if not all) actionable cases of mistake arising in this way are also actionable cases of misrepresentation. ${ }^{251}$ The theories are often pled in tandem, and because of their similarities, courts sometimes fail to give them full and separate treatment. ${ }^{252}$ The result is muddled invocation of the two defenses by both courts and lawyers. Indeed, when refusing to analyze both legal tests, some courts have noted that the theories are nearly coextensive. ${ }^{253}$ Nonetheless, given identical facts, technicalities make it possible to get different results from mistake and misrepresentation even though the adversely affected party seeks the same remedy with either defense. ${ }^{254}$ The cause of this maddening inconsistency is that mistake targets an actual harm-bargaining gone awry-whereas misrepresentation targets culpable behavior by the maker of a misrepresentation. Yet it is the very same culpable behavior that is often the cause of the adversely affected party's mistake, making misrepresentation redundant in many cases. ${ }^{255}$ A combined defense of misconception would reduce confusion among courts, attorneys, and students by requiring courts to apply a single set of factors instead of two sets of similar, but not iden-

250. See id. $\S 151$ ("A mistake is a belief that is not in accord with the facts.").

251. See supra Part III.

252. See, e.g., YTY Indus. SDN. BHD. v. Dow Chem. Co., No. CV 05-8881 SGL (AJWX), 2009 WL 3633871 , at *21 (C.D. Cal. Oct. 28, 2009) (refusing to consider buyer's defense of innocent misrepresentation and holding that the claim was subsumed by defense of mutual mistake); Shore Builders v. Dogwood, 616 F. Supp. 1004, 1012 (D. Del. 1985) (analyzing the defenses of mistake and innocent misrepresentation concurrently because the elements of both are similar); Platt v. Deese, 298 So. 2d 573, 577-78 (Fla. Dist. Ct. App. 1974) (granting relief for both gross mistake and gross misrepresentation); Kerlikowske v. Vill. of Stevensville, No. 206717, 1999 WL 33435655, at *2-3 (Mich. Ct. App. Sept. 28, 1999) (simultaneously considering innocent misrepresentation and mutual mistake as bases for preventing unjust enrichment); Alibri v. Detroit Wayne County Stadium Authority, 658 N.W.2d 167 (Mich. App. 2002) (mutual mistake and innocent misrepresentation argued as dual grounds for rescission); West Side Fed. Sav. \& Loan v. Hirschfield, 101 A.D.2d 380, 285 (N.Y. App. Div. 1984) (recognizing similarities between innocent misrepresentation and mutual mistake); Moore v. City of Beaumont, 195 S.W.2d 968, 988-89 (Tex. Civ. App. 1946) (finding that an innocent misrepresentation by the seller justified a defense of mutual mistake).

253. See id.

254. For instance, where a real estate contract contains an "as is" clause, relief is unavailable in mistake because the seller has assumed the risk, whereas relief may be available in misrepresentation so long as reliance is justified.

255. The notable exception, of course, is cases involving assumption of the risk of mistake by the adversely affected party as discussed in Part III. 
tical, factors. Combining the two defenses would produce greater efficiency and clarity in both pleadings and judicial decisions.

A second reason to prefer a combined defense of misconception to separate defenses of misrepresentation and mistake is the establishment of clear and achievable normative goals. While misrepresentation obviously is animated by normative aspirations that are different from those of mistake, it is ineffectual in accomplishing them. ${ }^{256}$ In part, this is because the remedy for misrepresentation, when pled in a defensive posture, is largely coextensive with the remedy for mistake, vitiating any purported normative distinction between the two. ${ }^{257}$ Yet misrepresentation is animated by different concerns than mistake is. Its focus on the nonconforming behavior of the misrepresenting party provides an opportunity to impose sanctions that will promote normative behavior. These sanctions should retain their restitutionary character by preventing the nonconforming party from benefiting from his misrepresentation. Sanctions could also seek to deter such behavior in the future and may even be perceived as punishing nonnormative behavior. Currently, the remedy for a successful misrepresentation defense accomplishes only the first of these three goals. The misrepresenting party is prevented from seeking enforcement of the contract, and he is required to return to the harmed party any benefits conferred upon him pursuant to the contract. ${ }^{258}$ In other words, the deal is unwound, and the parties are returned to their pre-contract positions to the greatest extent possible. ${ }^{259}$ Aside from possible reputational costs, the remedy leaves the misrepresenting party no worse off financially than he was prior to the failed bargain. In monetary terms, he is neither punished for his previous nonnormative behavior nor deterred from engaging in such behavior in the future. In most cases, the result for the wrongdoer is no different than if the adversely affected party had successfully invoked a defense of mistake. ${ }^{260}$ Why, then, struggle to maintain two separate defenses?

256. See supra Part III.

257. A successful mistake defense results in voidability of the contract coupled with restitution of any benefits conferred on the parties by one another. See RESTATEMENT (SECOND) OF CONTRACTS $\S \S \S 152,153,158$ (1981). The same is true for misrepresentation. 7 PERILLO, supra note $105, \S 28.23$. In cases of fraud, however, the restitutionary remedy available to the harmed party may be more extensive. See RESTATEMENT (FIRST) OF RESTITUTION $\$ 160 \mathrm{cmt}$. d (1937).

258. RESTATEMENT (SECOND) OF CONTRACTS $\$ 158 \mathrm{cmt}$. b (1981).

259. See id. ("Avoidance of a contract ideally involves a reversal of any steps that the parties may have taken by way of performance, so that each party returns such benefit as he may have received.").

260. Recall, however, that in the case of fraud, a court may force the misrepresenting party to not only disgorge benefits conferred upon her by the adversely affected party, but also any profits that the misrepresenting party eamed as a result of the fraud. See supra note 248. As described above, this additional remedial facet of fraud is not punitive and therefore is nothing more than an advanced form of restitution, more punitive only to a slight degree, and could be easily accommodated within the remedial portion of a combined defense. 


\section{B. Pushing Back Against a Combined Defense}

While a separate defense of misrepresentation may provide little satisfaction with regard to deterrence and punishment in a pragmatic sense, it nonetheless results in social stigmatization of the nonconforming party and justification of the adversely affected party's decision not to honor a legally binding promise or set of promises. This is particularly true when the adversely affected party alleges fraud. While the remedy provided by courts may not at first appear to be punitive in nature, perhaps social labeling and ostracism of the accused party is a sufficient punishment. Put in more concrete economic terms, while courts cannot require additional nonrestitutionary compensation on behalf of the adversely affected party when a fraud claim is brought in a defensive posture, the misrepresenting party may suffer both social shame and measurable monetary damage to its reputation and goodwill as a result of a successful defense. ${ }^{261}$ This, of course, assumes public awareness of judicial decisions, which is a questionable assumption at best.

A second possible reason to maintain a distinction between the two defenses is that fraud's current failure to achieve deterrence and punishment justifies fortification rather than abandonment of the defense. Perhaps the abstract possibility of social stigmatization is insufficient to support maintenance of a separate fraud defense. If so, the defense should be further differentiated from mistake through the addition of alternative or harsher sanctions for nonnormative behavior. This argument speaks only to remedy, however, and not to the determination of when a remedy is available. It does not foreclose the use of a combined test to determine the availability of rescission. Thus, the need to fortify the fraud defense presents no more than a weak argument against recognizing a combined defense of misconception in contract law, particularly when employed to determine whether a contract is voidable.

\section{Elements of a Combined Defense}

Several similarities emerge from the comparison of misrepresentation and mistake, and these similarities should serve as the starting point for the creation of a combined defense. The combined defense should satisfy normative concerns, such as efficiency and morality that are raised but not fully addressed by the current defenses. In addition, it should be capable of use in real life.

261. Goodwill, which is a rather abstract term in colloquial usage, has a concrete meaning in the business context. It is treated as an asset for tax and accounting purposes. See, e.g., 26 U.S.C. \& 197 (2012) (describing amortization of asset of goodwill for tax purposes). 


\section{Focusing on Adverse Effect}

At the outset, it is necessary to choose between mistake's focus on the adverse effect of failed bargaining and misrepresentation's focus on the relative culpability of the parties. The first approach is preferable because it is more comprehensive. An adversely affected party's consent may fail for reasons other than her counterparty's culpability. Choosing the second approach would leave parties whose mistaken belief arose from unspoken assumptions without recourse. As a result, the first prong of a combined defense should require the adversely affected party to prove that he held a belief not in accord with the facts at the time of contracting. This belief may have arisen from the assertion of a counterparty that was not in accord with the facts, but such an assertion should not be necessary. Here, the combined defense parts ways with misrepresentation's focus on nonnormative behavior. Instead, it turns its attention to the adversely affected party and identifies the point at which that party's internal conception of the bargain differed from the reality of the deal.

\section{Materiality of the Misconception}

The next task of a combined defense is to determine when a flaw in bargaining is so severe as to merit avoidance. Here, the defense must identify instances in which the adversely affected party's conception of the bargain differs from reality so much that she cannot be said to have given consent or received consideration for the deal. Both mistake and misrepresentation accomplish this task through the imposition of a materiality requirement: mistake asks whether the parties' performances have been thrown into gross imbalance, while misrepresentation asks whether the adversely affected party was induced by a false assertion. These two inquiries approach the question of consent from different directions. Mistake's materiality requirement is more objective in nature, while misrepresentation inquires about the state of mind of both the maker and the recipient of the assertion. Adopting a purely objective test for materiality would leave some cases of fraud-those with an unreasonably quirky victim - unaddressed. On the other hand, adopting a purely subjective inducement standard may create opportunities for disingenuous assertion of the defense and would also create difficulties of proof for the counterparty. The two inquiries can be reconciled by adopting a but-for test of materiality. ${ }^{262}$ The combined defense would be available only if the adversely affected party could show that but for the false belief, she would not have entered into the transaction. A but-for test would allow the adversely affected party to present evidence that would apply in a traditional objective analysis of the relative values of the parties' performances while still allowing her to present unique circumstances or char-

262. For cases adopting this rule in the context of fraud, see supra note 97. 
acteristics that influenced her consent to the bargain. This would ensure that the defense would only apply in cases where the mistaken belief led to a true failure of consent.

\section{Protecting Expectations of Counterparties}

\section{a. Protecting Counterparties from Conscious Ignorance}

Because there may be instances where justice requires enforcement of a contract despite prejudice to the adversely affected party, a combined defense should also embody a mechanism for protecting the expectation interests of innocent counterparties. In mistake, this is accomplished through allocation of risk, and in misrepresentation, it takes the form of a requirement of justified reliance. The analysis of justified reliance and assumption of risk through conscious ignorance or assignment of risk by a court are closely related. ${ }^{263}$ Courts generally find that a party was not justified in relying on a misreprentation when he did not exercise an ordinary amount of diligence. The misrepresentation defense is barred because he should have been aware of his lack of knowledge, or was aware of it, but he contracted anyway. The result is the same for assignment of risk based on conscious ignorance in mistake cases. It is reasonable to enforce a bar against the combined defense in such a situation as well because a rational party who contracts in conscious ignorance will have extracted a concession from his counterparty in return for his uncertainty. Alternatively, he will have concluded that the cost of further investigation outweighs the risk presented by his uncertainty and will contract even though he is unable to extract a concession. In either case, materialization of the risk, which may take the form of failure of a questionable representation, is merely a part of the bargain.

Allocating risk within a combined defense on the basis of conscious ignorance necessitates a discussion of what amount of diligence should be required of the adversely affected party. Customary diligence is the appropriate choice. In cases of mistake, a party must confirm uncertain facts through reasonable diligence. ${ }^{264}$ Courts and commentators have suggested that the requirement is less onerous in cases of misrepresentation, some of which only require cursory diligence. ${ }^{265}$ An examination of case law, however, reveals that "reasonable" and "cursory" are flexible words that grant a great deal of discretion to courts. The diligence inquiry is fact-bound, and courts consider both the expertise of the parties and the circumstances in which they find themselves. ${ }^{266}$ The discretion conferred by both mistake and misrepresentation can be captured with a requirement that the adversely affected party employ an amount of dili-

263. See supra Part III.C.

264. See cases cited supra note 44.

265. See supra Part III.B.

266. See id. 
gence that would be customary for a person in his position. This rule would require courts to consider the expertise of the parties, the circumstances in which they find themselves, and other evidence, including relevant state statutes and regulations indicative of trade custom and societal norms. A customary diligence rule would create an appropriate result in sophisticated business transactions, where more than cursory diligence is customary. It would also create an appropriate result for adversely affected parties in consumer transactions where unequal bargaining power and asymmetrical access to information make anything more than cursory diligence impossible.

\section{b. Protecting Counterparties Where an Adversely Affected Party Has Explicitly Assumed Risk.}

Where a party has explicitly assumed risk as part of the deal, the relationship between risk allocation and availability of the combined defense is more complicated. In cases of mistake, explicit assumption of risk bars invocation of the defense. For instance, a purchaser whose contract specifies that an item is sold "as is" has agreed to defects, open or hidden, as a part of the bargain. Parties who explicitly assume risk in this way are presumed to have bargained for concessions in return, so it cannot be said that there is a failure of consideration when the bargained-for risk materializes. Accordingly, courts will not declare these contracts voidable for mistake.

The Restatement's formulation of misrepresentation, by contrast, provides no corollary to mistake's prohibition on explicit assumption of risk. ${ }^{267}$ In the example above, where a purchaser buys goods "as is," the misrepresentation defense may apply as long as its other prongs are met. Here, misrepresentation reaches a different result from mistake and on different normative grounds. A purchaser is entitled to rely on the seller's representations unless a cursory investigation would reveal that they are untrue, and this reliance is unaffected by explicit assumption of risk unless that assumption takes the form of a disclaimer of representations or waiver of the purchaser's right to assert a misrepresentation defense. So while the purchaser cannot assert mistake, she may prevail on grounds of misrepresentation. This disparity must be accounted for in a combined defense, and there are three possible ways to address it. The first possibility is to apply the bar on explicit assumption of risk to misconceptions arising from both mistake and misrepresentation. The second possibility is to apply it to neither. The third and best choice is to refine the bar on explicit assumption of risk to account for concerns raised by either factual scenario. To choose from among these options, it is necessary to understand the reasons why mistake and misrepresentation differ on this front.

267. See generally RESTATEMENT (SECOND) OF CONTRACTS ch. 7 (1981) (describing the misrepresentation defense). 
i. Barring a Misrepresentation Defense on the Basis of Explicitly Assumed Risk Prejudices the Adversely Affected Party.

The first possible solution, applying the explicit assumption of risk bar to misrepresentation cases, is a poor choice because the normative grounds for misrepresentation differ from mistake. First, there are moral grounds for protecting the hearer of a misrepresentation, i.e., people should be entitled to reasonably rely on representations of a counterparty. So long as the hearer's reliance is reasonable, the law prefers the hearer, who is blameless, over the maker of the misrepresentation. Second, a party who makes a representation during bargaining is likely to have superior information and should be presumed to have such information about the object of the representation. If the adversely affected party could lose an available defense on the basis of explicit assumption of risk or assignment of risk for conscious ignorance, no party could comfortably rely on any representation. Hearers of representations would be forced to conduct a cost-benefit analysis on the investigation of each representation. The likely result would be an inefficient replication of information already in the possession of the counterparty. ${ }^{268}$ From an efficiency standpoint barring a misrepresentation defense on the basis of assumed risk makes little sense.

A third, more convincing reason is that a party who bargains with reference to her counterparty's misrepresentation and who intentionally assumes risk as part of that bargain is misled about the magnitude of the assumed risk. Such a bargain should not be enforced because the flawed bargaining process constitutes a failure of consent or consideration. For instance, assume that George buys a car from Henry. Henry makes no representations about the mechanical integrity of the car, and George buys the car "as is." George has a full opportunity to assess the magnitude of the risk that he will assume under the contract, and he can bargain for a lower price or other consideration accordingly. Perhaps the car is worth $\$ 5000$ in good working order but only $\$ 3000$ if the transmission fails. Since George knows of the risk that the transmission will fail and that he will bear the cost, he may only be willing to pay $\$ 4000$ for the car. In this case, George has valued his assumption of the risk at $\$ 1000$. In contrast, if Henry tells George that the car has a working transmission, George will discount the risk presented by the "as is" clause. As a result, he will demand less from Henry in return for his assumption of that risk. Instead of offering to pay $\$ 4000$ (and demanding a $\$ 1000$ concession in return for his assumption of the risk of transmission failure), George may

268. See Jeffrey L. Harrison, Rethinking Mistake and Nondisclosure in Contract Law, 17 GEO. MASON L. ReV. 335 (2010). Professor Harrison's interesting discussion focuses on disclosure and includes a proposal for permitting non-disclosure "only when it is consistent with positive allocative ends." Id. at 366. For more analysis of this issue, see also Richard Craswell, Taking Information Seriously: Misrepresentation and Nondisclosure in Contract Law and Elsewhere, 92 VA. L. REV. 565, 61822 (2006). 
offer $\$ 4750$, valuing the "as is" clause at a mere $\$ 250$ on the basis of Henry's representation. ${ }^{269}$

In the second example above, it is clear that George should be forced to bear the risk of transmission failure to the extent of $\$ 250$. He exchanged his assumption of that burden in exchange for the benefit of a lower price in the bargaining process. The status of the remaining $\$ 750$ of risk is less clear because Henry's faulty representation prevented George from considering it during their negotiations. George cannot be said to have truly assumed that portion of the risk because he did not bargain with reference to it. As a result, he demanded no concession from Henry in return, primarily because Henry's representation discouraged him from doing so. Henry should not benefit from George's incorrect assessment of the magnitude of the risk when Henry's faulty information caused it. In this case, a court should find that George did not asassume the entire risk of transmission failure; rather, he assumed only a portion of it. As a consequence, a court could reasonably conclude that the misrepresentation defense should apply to the case, assuming that the other prongs of the test were satisfied. Mistake and misrepresentation seem to part ways here, which militates against a conclusion that mistake could seamlessly incorporate misrepresentation. Finally, this analysis demonstrates that as long as an adversely affected party's reliance is justified, the misrepresentation defense should not be barred as a result of explicit assumption of risk.

ii. Refusal to Bar a Combined Defense on the Basis of Explicit Assumption of Risk in All Cases Prejudices the Nonadversely Affected Party in Some Cases.

A second possible way to reconcile assumption of risk in mistake and justified reliance in misrepresentation is to simply eliminate the bar on invocation of a defense where an adversely affected party has assumed the risk of mistake. Like the first choice-uniformly applying the bar-this choice is untenable. As described above, where a party has explicitly assumed the risk of mistake in a contract, he will (or should) have bargained for some concession in return for the risk. Because it is bargained for, fruition of the risk does not deprive the adversely affected party of consideration in the deal. Instead, the result is quite the opposite; in these cases, the adversely affected party has gotten exactly what she bargained for, even if she hoped that the risk would not materialize. Refusing to bar the mistake defense in cases of explicit assumption of the risk would unduly prejudice the counterparty, robbing him of the benefit of his bargain. Likewise, where an adversely affected party in a misrepresentation case has waived his right to assert the defense as a part of the

269. I have not chosen a zero value for the risk because the "as is" clause presents some risk and also because George reasonably may conclude that Henry has imperfect information about the mechanical soundness of the car. 
contract, or where the counterparty has insisted on including explicit disclaimer language in the contract, it is proper for a court to assume that the adversely affected party acted rationally by exacting some concession in return for the waiver or disclaimer. Refusing to bar the misrepresentation defense in such cases would again rob the counterparty of the benefit of her bargain. Consequently, a combined defense should not eliminate the bar to recovery in cases of explicit assumption of the risk.

iii. The Assumption of Risk Bar Should Extend Only So Far As The Parties' Bargained-For Allocation of Risk.

Application of the combined defense should be barred on the basis of explicit assumption of risk only when the defense hinges on fruition of the explicitly assumed risk. Furthermore, the adversely affected party's reasonable reliance on a misrepresentation about the magnitude of the explicitly assumed risk should establish a presumption that risk associated with the subject matter of the fraud was not willingly assumed by the adversely affected party. Universally barring a combined defense on the basis of assumption of risk would be overly broad, depriving the adversely affected party of the benefit of her bargain, and refusing to apply the bar at all would have the opposite effect. A combined defense instead should apply the bar in a way that respects the bargain reached by the parties. This may, in essence, make application of the bar a question of contract interpretation. Courts would look to the parties' express language, course of dealing, course of performance, trade custom, and other vehicles of interpretation to determine the breadth of the adversely affected party's assumption of risk.

This approach was applied by Washington's high court in Nevue $v$. Close, which dealt with a disputed legal settlement. 270 The defendant in that case previously had agreed to a settlement of the plaintiff's claims arising from a car accident. ${ }^{271}$ At the time, the plaintiff knew she suffered from a minor neck sprain. ${ }^{272}$ After signing a settlement agreement, she discovered a serious back problem that had been masked by her pregnancy at the time of settlement. She sued the defendant, who argued that the suit was barred by the settlement agreement. ${ }^{273}$ The plaintiff, in turn, argued that the settlement agreement was voidable on the basis of mutual mistake. ${ }^{274}$ The court held that "the later-discovered back injury was not contemplated by the parties" at the time of contracting and that the plaintiff's suit "should not be foreclosed by the 'boiler-plate' general release language" in the agreement. ${ }^{275}$

270. See 867 P.2d 635 (Wash. 1994).

271. Id. at $635-37$.

272. Id. at $636-37$

273. Id. at 637

274. Id. at $636-37$

275. Id at 637 . 
The Nevue case is useful to the contemplation of a combined defense because the court looked beyond the surface of the plaintiff's explicit assumption of risk and instead asked how much risk was actually assigned to her in the bargain; this was an exercise in contract interpretation. The court considered not only the bare language of the agreement but also the circumstances and knowledge of the parties at the time of contracting to determine whether the general release could have extended to risks not contemplated by the parties at that time. Put more abstractly, a court could have determined that the plaintiff had bargained for a return on risk $\mathrm{X}$ but had not similarly bargained for a return on risk $Y$ because she could not have been aware of it. When risk $Y$ presented itself in the form of a latent back injury, plaintiff was not forced to bear that risk under the court's interpretation of the contract.

The Nevue case falls short, however, of presenting a complete solution to overinclusiveness of the potential bar against a mistake defense in cases where the mistake is caused by a misrepresentation and where the adversely affected party assumed risk in the bargain. This is because the mistake in Nevue did not result from a misrepresentation by the defendant and instead turned on the fact that the risk had not been contemplated by the parties at the time of contracting. What if the risk had been contemplated by the parties? This is necessarily the case whenever one party makes a representation to the other with regard to the risk at issue. For instance, what if the defendant had been the plaintiff's physician? Suppose that after apologizing profusely for the accident, the defendant told the plaintiff that while she could have sustained a latent back injury, an examination showed that she had not. The Nevue analysis is no longer appropriate because the parties clearly contemplate the possibility of plaintiff's back injury. Nonetheless, when the plaintiff signs a general release of claims in return for compensation, she believes that she has assumed only risk $\mathrm{X}$ and has bargained for a return on only that risk. As a result of the defendant's misrepresentation, she has not bargained for a return on risk $\mathrm{Y}$, the risk of the latent back injury. Consequently, invocation of the defense should not be barred with regard to risk $Y$.

A combined defense should incorporate explicit assumption of risk as a bar against invocation of the defense only to the extent that the adversely affected party could have been aware of the magnitude of the risk assumed or was aware of his own ignorance with regard to the magnitude of that risk. In the example the plaintiff could not avoid her general waiver of claims with regard to latent injuries that could have been contemplated by the parties at the time of settlement. But because the defendant's specific misrepresentation removed back injury from the plaintiff's calculus, her use of the defense should not be barred on grounds that she assumed the risk by agreeing to the general release of claims. A court could reach this result through interpretation of the clause itself, in a slightly broader fashion than in Nevue. Alternatively, the misrepresentation could create a presumption in favor of the adversely affected par- 
ty; if she reasonably relied on it, then she could not have known the magnitude of the risk and should be presumed not to have assumed it. Either way, the assumption of risk prong of the mistake test could be incorporated into a combined defense, which avoids overbreadth yet still respects the bargain reached by the parties. Assumption of risk, then, does not create a barrier to creation of a combined defense.

\section{Choosing a Remedy: Protecting Normative Underpinnings of the Fraud Defense}

Like current iterations of the mistake and misrepresentation defenses, a combined defense based on misconception should result in a voidable contract, coupled with restitution. This remedy returns the adversely affected party to her precontract status to the greatest extent possible. Since she never truly consented to the deal and now refuses to ratify it, unwinding it is more appropriate than forcing her to remain in the transaction and receive damages. A question arises, though, as to the scope of restitution. If a combined defense took the approach of mistake and focused solely on harm to the adversely affected party, then "restitution" would mean that the counterparty returned any benefits transferred by the adversely affected party, and vice versa. If a combined defense took the approach of fraudulent misrepresentation and focused not only on unjust enrichment, but also on deterrence and possibly punishment, then "restitution" should be construed more broadly to forward (or at the very least, not to impede) these goals in cases where a misconception arises from fraudulent misrepresentation. Finally, punitive damages should be available in cases of fraud. A flexible approach to remedies, combining rescission with restitution, disgorgement, and punitive damages, would allow courts to efficiently address the question of rescission's availability while still preserving the ability of a combined defense to punish and deter fraud. ${ }^{276}$

\section{Disgorgement of Profit}

When a mistake arises not as a result of a misrepresentation, but instead from the adversely affected party's own assumptions about a deal, deterrence is not an issue. The counterparty has not engaged in nonnormative behavior, so there is nothing to deter. In addition, because the adversely affected party's interest is not harmed by any action of the counterparty, punishment is also inappropriate. As a result, disgorgement of profits and punitive damages are not warranted. In cases of pure mistake that do not involve a false assertion by a counterparty,

276. For another proponent of allowing courts discretion in choosing a remedy, see 7 PERILLO, supra note $105, \S 28.44$, at 277 ("It is still advantageous for our common jurist to be able to choose among a variety of remedies, enforceable by a variety of processes."). Also, "[t]he power of the courts to make the remedy fit the special case is not extinct." Id. 
restitution should be confined to disgorgement by the counterparty of benefits conferred by the adversely affected party. ${ }^{277}$

In cases where misrepresentation arises through nonfraudulent misrepresentation, the analysis is less clear. Although disgorgement is currently available only in select cases of fraud, this remedy is not punitive because it does not leave the maker of the misrepresentation in a worse position than if no contract had been made. It does have deterrent value, however, in the sense that it removes an incentive to nonnormative behavior. Although the maker of a nonfraudulent misrepresentation has no intention to mislead his counterparty, and therefore cannot be deterred from doing so, he is still at fault for a flaw in bargaining, possibly as a result of his negligence. Failing to require disgorgement of profit would allow him to benefit from a bargaining flaw that he caused, which incentivizes his lack of care. Disgorgement may encourage an appropriate level of investigation by removing this incentive. On the other hand, requiring disgorgement of profit in these cases may encourage excessive investigation and use of disclaimer language, or it may chill parties' willingness to make assertions during bargaining, even when those assertions are probably true. This may result in added transactional costs and may result in fewer contracts at the margin. Without empirical evidence, it is difficult to know whether bargaining would be affected by a requirement for disgorgement of profit in cases of nonfraudulent misrepresentation. As a result, I reach no conclusion on the matter here.

In cases of fraud, the answer is clear: courts should require disgorgement of profits. A failure to require disgorgement of profits would encourage nonnormative behavior by improving the position of the misrepresentation's maker even if he is stripped of every benefit conferred by the adversely affected party through restitution. Leaving the perpetrator of fraud in possession of profits essentially makes fraud a breakeven proposition in financial terms and incentivizes the rational actor by increasing the expected return on the legal risk associated with fraud. ${ }^{278}$ Furthermore, there would seem to be no purer form of unjust enrichment than profit earned through fraud. As a consequence, courts should require disgorgement of profits within the defense of misconception in cases of fraud.

277. Perhaps it could be argued that because mistake negates the adversely affected party's consent, the counterparty should be deemed to hold the transferred goods or services on the adversely affected party's behalf. If so, the counter party should be forced to remit profits to the adversely affected party. A counterargument to this position is that because the profits are created by the counterparty, they should belong to that party. Alternatively, retention of profits could compensate the counterparty for her stewardship of the transferred good or services.

278. Of course, reputational costs may change the calculus in some cases. 


\section{Punitive Damages}

In cases of fraudulent misrepresentation, courts should be permitted to award punitive damages. ${ }^{279}$ While rescission and garden-variety restitution are adequate to return the adversely affected party to his precontract position, they are inadequate means of deterrence and punishment for fraud because they leave the adversely affected party financially no worse off than if the fraud had not been committed. Both tort law and state law have recognized this problem, and both bodies of law allow courts to award punitive damages in fraudulent misrepresentation cases where tort-like conduct is present. ${ }^{280}$ Accordingly, courts should have discretion to award punitive damages for fraud in the combined defense of misconception.

\section{a. Tort Law, State Statute, and Restitution in the Noncontractual Context Close Misrepresentation's Normative to Positive Gap}

Failure of the common law of contracts to consistently address normative goals of punishment and deterrence within the misrepresentation defense has led to state statute and tort law promoting these goals. The presence of explicit differentiation between fraudulent and negligent misrepresentation in the remedies provided by tort and state statutory law strongly suggests that such differentiation should be considered in a combined contract defense as well.

\section{i. The Tort of Deceit}

While the common law of contracts only provides a defensive remedy for misrepresentation - voidability of the contract coupled with restitution-tort law provides the adversely affected party with a theory of liability for which monetary damages are available. ${ }^{281}$ The tort action for fraud is commonly referred to as deceit; however, misrepresentation in tort is broader than deceit. ${ }^{282}$ Like contract law, it may encompass negligent misrepresentation as well as nondisclosure. ${ }^{283}$ An advantage of deceit is that an adversely affected party may retain what she received rather than completely unwind the deal. ${ }^{284}$ For instance, assume that Matt and Jessica each buy a vintage Stratocaster. On each instrument, the pickguard has been replaced, and in both cases, the seller fraudulently represented that all of the parts were original. Matt, a collector, does not want a guitar with replacement parts, but Jessica, a rock musician, wants

279. See Boise Dodge v. Clark, 453 P.2d 551, 558 (Idaho 1969) (awarding punitive damages awarded against a car dealer who rolled back the odometer).

280. See E. Allan FARNSWORTH, FARNSWORTH ON CONTRACTs $\$ 12.8$, at 196-98 (3d ed. 2004) (stating that punitive damages may be awarded in cases involving tort, including fraud).

281. RESTATEMENT (SECOND) OF TORTS $\$ 549$ (1977).

282. Dan B. Dobbs ET AL., Prosser ANd KeEton on THE LAW of TorTs 727 (5th ed. 1984).

283. Id. at 726.

284. See RESTATEMENT (SECOND) OF TORTS $\$ 549$ (1977). 
to play the instrument. In litigation, Matt will choose the contract defense. He does not want the guitar at all and wishes to unwind the entire transaction. Jessica, on the other hand, will choose the tort of deceit, which will allow her to retain the instrument but receive damages in the amount of the expected value of the guitar less its actual value. Put more plainly, in a tort claim for misrepresentation, Jessica has chosen to stick with the bargain and sue for the amount by which the bargain has not lived up to her expectations. In addition, Jessica may be entitled to punitive damages in tort, but Matt has no such recourse under the common law of contracts. The disparity makes little sense given the coidentity of the harm in these two cases.

The elements of the tort claim of deceit are nearly identical to those of the fraudulent misrepresentation defense in contract law. The first element of the tort claim is a misrepresentation made by the defendant, which is a representation not in accord with the facts. ${ }^{285}$ It usually consists of oral or written words, but in some cases, other misleading behavior may be actionable. ${ }^{286}$ As with the contract defense, conduct may also be a misrepresentation if it is calculated to convey a misleading impression. ${ }^{287}$ Deceit's second element is scienter, which is the intent to deceive, mislead, or convey a false impression. ${ }^{288}$ Scienter relates to yet a third element of deceit that mirrors contract law, an intention to induce the plaintiff to act or refrain from acting on the misrepresentation. ${ }^{289}$ The fourth element requires the plaintiff's justified reliance on the misrepre-

285. See id. \$\$ 525, 526 .

286. KEETON ET AL., supra note 65 , at 736 . Generally, a plaintiff may not bring a case for deceit on allegations that the defendant's silence or non-disclosure of a known fact forms the representation. Id. at 737. Exceptions exist, but they are "ill defined" with "no very definite boundaries." Id. at 738 . Non-disclosure is a false representation when the defendant discloses only enough information to mislead the plaintiff into believing the half-truth is whole. Id. See also RESTATEMENT (SECOND) OF TORTS $\$ 529 \mathrm{cmt}$. a (1977) ("A statement containing a half-truth may be as misleading as a statement wholly false."). To count as a misrepresentation, the maker of the statement must know or believe that the omitted facts would affect the other party's conduct in their dealings; a belief that the omitted facts would not affect the value of the thing bargained for is irrelevant. $I d$. $\$ 529 \mathrm{cmt}$. b. A second exception occurs when the parties are in a confidential or fiduciary relationship to one another. KEETON ET AL., supra note 65, at 738; see also RESTATEMENT (SECOND) OF TORTS $\$ \$ 551(2), 551 \mathrm{cmt}$. a (1977). Examples include the following: principal and agent, executor and beneficiary, majority and minority shareholders, and old friends. KEETON ET AL., supra note 65 , at 738 . A trend among courts finds a duty to disclose under circumstances where a failure to disclose goes against what an ordinary, ethical person would have disclosed. Id. at 739. Factors of importance include: difference in degree of intelligence, relation of parties to each other, manner in which information was acquired, nature of the fact not disclosed, class of the person with the information, nature of the contract, and active concealment of a material fact. Id. For example, sellers are more likely to be required to disclose than buyers, and insurance contracts require disclosure of all material facts. Id.

287. KEETON ET AL., supra note 65 , at 736 . For example, an action intended to prevent the other party from acquiring material information is treated as though he had stated the nonexistence of the concealed fact. RESTATEMENT (SECOND) OF TORTS $\$ 550$ (1977).

288. KEETON ET AL., supra note 65 , at 741 . The false representation must be made knowingly or with reckless carelessness about whether it is true or false. The defendant must believe that the statement is false, not believe the statement is true, or know that he lacks sufficient information to justify the statement. The defendant's honest belief, though unreasonable, that the statement is true is not an intent to deceive but is instead simply negligence. Id. at 741-42.

289. RESTATEMENT (SECOND) OF TORTS $§ 531$ (1977). 
sentation. ${ }^{290}$ Materiality is the fifth element: ${ }^{291}$ to ensure that the plaintiff is not using an unimportant misrepresentation as the pretext for escaping a regrettable agreement, the misrepresentation must not be trivial. ${ }^{292} \mathrm{~A}$ misrepresentation is material for this purpose if either an objective, reasonable person would view it as important or if the defendant knew that the plaintiff would regard it as important. ${ }^{293}$ Here, the tort inquiry mirrors the Restatement Second of Contracts' discussion of the materiality of a misrepresentation. ${ }^{294}$ Finally, in keeping with other areas of tort law, deceit requires the plaintiff to suffer damage as a result of his reliance on the false representation. ${ }^{295}$

\section{ii. Distinguishing Fraud from Nonfraudulent Misrepresentation.}

Tort law's focus on the state of mind of the maker of a misrepresentation is indicative of its underlying normative motivations. Historically, scienter was a necessary element of the tort claim of misrepresentation, but some jurisdictions allow recovery for negligent and innocent misrepresentations, just as in contract law. ${ }^{296}$ According to the Restatement Second of Torts, a plaintiff may recover money damages for negligent misrepresentation where either the misrepresentation resulted in a risk of physical harm or pecuniary loss. ${ }^{297}$ Finally, a minority of jurisdictions even allow plaintiffs to bring a strict liability claim, colloquially referred to as innocent misrepresentation. ${ }^{298}$ The Restatement Second of Torts summarizes the cause of action for innocent misrepresentation: "One who... makes a misrepresentation of a material fact for the purpose of inducing the other to act or to refrain from acting in reliance upon it, is subject to liability... even though it is not made fraudulently or negligently."299

290. Id. \$537; KEETON ET AL., supra note 65 , at $750-51$. With regard to this prong of the test, a court may bar recovery for two reasons: the court doubts the plaintiff relied on the false representation, or the court accepts that the plaintiff relied on the representation but bars recovery because plaintiff's reliance is foolish. Id. at 750 . As in contract law, the reasonable person may not rely upon a ridiculous statement. Id. at 751. Similarly, while an ordinary person might rely on a statement and recover, one with special knowledge of the subject at issue may not rely on that same statement. $I d$.

291. RESTATEMENT (SECOND) OF TORTS $\$ 538$ (1977).

292. KEETON ET AL., supra note 65, at 753.

293. Id.

294. RESTATEMENT (SECOND) OF TORTS $\$ 538$ (1977) ("Reliance upon a fraudulent misrepresentation is not justifiable unless the matter misrepresented is material.").

295. See Brooks v. Dime Sav. Bank of New York, FSB, 457 S.E.2d 706, 707 (Ga. Ct. App. 1995) (dismissing the case when plaintiffs failed to produce evidence of damages). The plaintiff must have suffered substantial damage before the cause of action can arise. KEETON ET AL., supra note $65, \S 110$, at 765. Nominal damages will not be awarded in deceit. Id. No recovery is permitted if plaintiff is not worse off because of the misrepresentation. Id.

296. RESTATEMENT (SECOND) OF TORTS $\$ 552 \mathrm{C}$ (1977); see also KEETON ET AL., supra note 65, $\S 107$, at 740 .

297. Id. § 311 , cmt. a; id. $\S 552 \mathrm{cmt}$. a.

298. Id. \& 552C.

299. Id. $\$ 552 \mathrm{C}(1)$. Cases to which this strict liability for innocent misrepresentation have "been applied thus far have generally been confined to sale, rental or exchange transactions between the plaintiff and the defendant" and the limits of this liability have not yet been determined. $I d$. at cmts. c, 
The presence of both fraudulent and negligent misrepresentation in tort law mirrors dichotomies in contract law between unilateral and mutual mistake, between material and fraudulent misrepresentation, and between mistake and misrepresentation. As with the contract defenses, tort claims' differing focus on mental state reflects underlying normative differences. The tort of deceit, which is equivalent to the contract defense of fraudulent misrepresentation, may be motivated not only by an imperative to make the adversely affected party whole but also by the pragmatic need to deter and the moral need to punish nonnormative behavior. Because the maker of a negligent or innocent misrepresentation is less blameworthy, tort law provides a separate cause of action, just as contract law does. Unlike contract law, however, tort law explicitly provides for different remedies based on the maker's mental state. As a result, tort law more effectively matches its normative goals to its positive outcomes.

Damages in tort actions for misrepresentation are calculated using either the out of pocket standard, which applies to negligent misrepresentation, or the benefit of the bargain standard, which applies to deceit. ${ }^{300}$ Damages measured under the out of pocket standard are those necessary to compensate the plaintiff for pecuniary loss caused by the misrepresentation. ${ }^{301}$ The out of pocket measure includes " $[\mathrm{t}]$ he difference between the value of what he has received in the transaction and its purchase price or other value given for it; and... [p] ecuniary loss suffered otherwise as a consequence of the plaintiff's reliance upon the representation." 302 The damages do not include the benefit of the plaintiff's contract with the defendant, and in this sense, they are consistent with

g. This section appears to be followed in twelve states and may be accepted in five other states. Id. at Reporter's Note.

300. Id. \$549. A minority of jurisdictions do not recognize the benefit of the bargain standard. See 1 PALMER, supra note 242, at $\$ 3.8$, at 263-64 (explaining that a minority of states, including New York, limit the plaintiff to out-of-pocket losses). In Texas, both standards are recognized for fraudulent misrepresentations; the benefit of the bargain standard includes " lost profits ... that would have been made if the bargain had been performed as promised." LHC Nashua P'ship, Ltd. v. PDNED Sagamore Nashua, L.L.C., 659 F. 3d 450, 462 (5th Cir. 2011) (quoting Formosa Plastics Corp. USA v. Presidio Eng'rs \& Contractors, Inc, 960 S.W.2d 41, 50 (Tex. 2011)). Texas does not recognize benefit of the bargain damages for negligent misrepresentation. See id. The Georgia courts similarly apply benefit of the bargain for fraudulent misrepresentations and out of pocket damages for negligent misrepresentations. See BDO Seidman, LLP v. Mindis Acquisition Corp., 578 S.E.2d 400 (Ga. 2003). Georgia courts held the benefit of the bargain standard has no application in a negligent misrepresentation case. See id. Of course, there are exceptions. A few states permit benefit of the bargain damages for a negligent misrepresentation claim. In Utah, even though the court referenced the Restatement, it determined the proper calculation of damages for a negligent misrepresentation was the difference between what the plaintiff thought the value was and the actual value of the property. See Forsberg v. Burningham \& Kimball, 892 P.2d 23, 27 (Utah 1995). The court purports to follow the Restatement; however, the Restatement calculation of damages would be the difference between the value received and the purchase price. Also, seven jurisdictions limit liability to out of pocket damages even for deceit. See RESTATEMENT (SECOND) OF TORTS \$ 549, Reporter's Note 2 (1965). In Montana, in an action based on fraud, the measure of damages is the difference between the actual value at the date of the sale and the contract price, which is essentially the same as the Restatement out of pocket standard. See Denny v. Brissonneaud, 161 Mont. 468, 473 (1973).

301. BDO, 578 S.E.2d at 401.

302. Id. 
traditional tort damages and mirror reliance damages in contract law. ${ }^{303}$ A more punitive measure of damages, the benefit of the bargain standard, applies in cases of fraud. ${ }^{304}$ It gives the wronged party the benefit of the contract he made, and it ensures that the defendant does not benefit from her fraudulent misrepresentation. ${ }^{305}$ In this regard, the benefit of the bargain standard mirrors expectancy damages in contract law. ${ }^{306}$ While not considered punitive in contract law, permitting a plaintiff to recover the benefit of her bargain is an extraordinary remedy in tort, which is typically limited to only those damages that are compensatory, i.e., those that make the damaged plaintiff whole. ${ }^{307}$ The benefit of the bargain measure, however, places the plaintiff in his post-contract position, which in most cases will not only make him whole but will also make him better off. ${ }^{308}$ In this regard, the benefit of the bargain standard reflects the difference in the normative underpinnings of negligent and fraudulent misrepresentation and is punitive within the context of tort law.

Tort law embodies a second significant difference in the damages awarded for fraudulent misrepresentation claims: the availability of punitive damages. ${ }^{309}$ In some states, punitive damages are available in any case where the adversely affected party proves fraud. ${ }^{310}$ In others, punitive damages are available only for truly egregious conduct. ${ }^{311}$ Here, normative goals of deterrence and punishment are clearly supported by positive law. Courts award punitive damages in deceit cases to punish an offender and deter others but not to compensate the plaintiff. ${ }^{312}$ When crafting a punitive damage award, a court focuses solely on the culpability of the maker of the misrepresentation. ${ }^{313}$ Consequently, "[m]ore than

303. See RESTATEMENT (SECOND) OF TORTS § 552B(2) (1977); see also Jill Wieber Lens, Honest Confusion: The Purpose of Compensatory Damages in Tort and Fraudulent Misrepresentation, 59 KAN. L. REV. 231, 235 (2011) (stating that tort damages generally are compensatory in nature).

304. See RESTATEMENT (SECOND) OF TORTS $\$ 549$ (1977); BDO Seidman, LLP, 578 S.E.2d at 401-02.

305. $B D O, 578$ S.E. 2 d at 402.

306. See 1 PALMER, supra note $242, \S 3.8$ (stating that most jurisdictions have adopted a contract measure of damages for the tort of deceit in order to put plaintiff in position she would have occupied if the defendant's representations had been true). For an interesting discussion of this point, see Lens, supra note 303 , at $243-48$.

307. Lens, supra note 303 , at 248 (noting that the benefit-of-the-bargain standard is more than compensatory, as it aims to place plaintiff in better position than pre-bargain position).

308. Id.

309. See Block v. Tobin, 119 Cal. Rptr. 288, 290-91 (Cal. Ct. App. 1975); Van Sickle Const. Co. v. Wachovia Commercial Mortg., Inc., 783 N.W.2d 684, 689 (Iowa 2010); Walker v. Sheldon, 179 N.E.2d 497, 498 (N.Y. 1961); ); see also Watkins Rest. Co. v. Rabideau, Case No. L-80-123, 1981 WL 5760, at *5 (Ohio Ct. App. Aug. 21, 1981). For a summary of punitive damages in tort actions for deceit, see Lens, supra note 303 , at $274-75$.

310. Lens, supra note 303, at 275.

311. Id.

312. See Foust v. Valleybrook Realty Co., 446 N.E.2d 1122, 1128 (1981).

313. See Walker, 179 N.E.2d at 498 (punitive damages available only in cases of gross and wanton tort fraud); Van Sickle, 783 N.W.2d at 689 (Iowa 2010) (holding that more than mere negligence is necessary to support claim for punitive damages in misrepresentation case); PM Group, Inc. v, Stewart, 154 Cal.App. 4th 55, 69 (Cal. App. 2 Dist. 2007) ("[I]t is well settled that punitive damages are not recoverable for negligent misrepresentation."). 
negligent conduct is required to support a punitive damage award." 314 The common law of contracts contains no such dichotomy, and as a result may be viewed as ineffectual at accomplishing the normative goals of punishment and deterrence that are typically associated with successful fraud claims. A combined defense of misconception should address this deficit by allowing punitive damages in cases of fraud.

\section{iii. State Statutory Protections Against Fraud}

Like tort law, states' consumer protection laws allow harsher remedies in cases of fraud. Twenty-five states and the District of Columbia allow statutorily enhanced damages, such as treble or punitive damages. $^{315}$ For example, New York's consumer protection statute permits treble damages up to one thousand dollars, ${ }^{316}$ while Ohio's consumer protection law allows unlimited treble damages. ${ }^{317}$ Additionally, in Ohio, consumers may either rescind their transaction or recover treble damages, ${ }^{318}$ but in California, consumers are permitted to both rescind the transaction and collect punitive damages. ${ }^{319}$ Other states' consumer protection laws, such as those of Connecticut, ${ }^{320}$ Idaho, ${ }^{321}$ and Oregon, ${ }^{322}$ allow for punitive damages to be awarded at the court's discretion. Additionally, under Idaho's consumer protection law, aged or disabled plaintiffs are automatically entitled to statutory damages of the greater of fifteen thousand dollars or treble damages. ${ }^{323}$ These statutory schemes highlight a societal consensus that fraud should be deterred and punished. Where rescission is a desirable remedy-perhaps the consumer cannot pay or the good or service is of poor quality - the common law remedy of restitution plus disgorgement of profit is insufficient to deter or punish the wrongdoer, because it leaves her no worse off than if she had not committed the fraud. As a result, state legislatures have enacted harsher remedies, which once again highlights important normative differences between the defenses of mistake or innocent misrepresentation on one hand and fraud on the other.

314. Van Sickle, 783 N.W.2d at 689.

315. Carolyn L. Carter, National Consumer law CEnTER InC., Consumer Protection IN THE STATES: A 50-STATE REPORT ON UNFAIR AND DECEPTIVE ACTS AND PRACTICES STATUTES 23 (2009), available at http://www.nclc.org/images/pdf/car_sales/UDAP_Report_Feb09.pdf.

316. N.Y. GEN. BUS. LAW § 349(h) (McKinney 2013).

317. OHIO REV. CODE ANN. $\$ 1345.09$ (West 2013).

318. Id.

319. CAL. CIv. CoDE § 3294(a) (West 2013); see also Millar v. James, 62 Cal. Rptr. 335, 337

(Cal. Ct. App. 1967) ("[T] he fact that the plaintiff's recovery was in the form of specific restitution, rather than monetary damages, does not necessarily preclude an award of exemplary damages.").

320. CONN. GEN. STAT. ANN. $\$ 42-110 \mathrm{~g}$ (West 2013).

321. IDAHO CODE ANN. \$ 48-608 (West 2013).

322. OR. REV. STAT. ANN. $\$ 646.638$ (West 2013).

323. IDAHO CODE ANN. § 48-608 (West 2013). 


\section{iv. Restitutionary Remedies in the Noncontractual Context}

The enlarged scope of remedies available for fraud in tort law and state statutes also exists in the common law of restitution, though not to the same extent. Here, I refer not to the remedy of restitution awarded in a successful contract defense but to a claim of unjust enrichment for non-consensual transfer. ${ }^{324}$ In cases of mistaken transfer, a plaintiff who brings a successful restitution claim is entitled to a return of the benefit conferred by the plaintiff on the defendant. ${ }^{325}$ In some cases of fraud, the defendant may be deemed to hold the transferred assets in constructive trust for the plaintiff ${ }^{326}$ or simply may be ordered to disgorge profits that arise from the transaction. ${ }^{327}$ Disgorgement is a harsher remedy that once again reflects the underlying normative distinctions between mistake and fraud. It not only prevents unjust enrichment of the defendant but also removes an incentive for the defendant to engage in nonnormative behavior. ${ }^{328}$ Disgorgement does not punish fraudulent behavior in the same manner as punitive damages, however. It leaves the defendant no worse off than if he had not committed the fraudulent act and is therefore not punitive. ${ }^{329}$ Regardless, it presents a third example of differentiation in remedies available to parties who unravel transactions as a result of fraud rather than as a result of mistake and suggests that retaining rather than abolishing this distinction in a combined defense would be consonant with societal norms. ${ }^{330}$

324. See RESTATEMENT (SECOND) OF CONTRACTS chs. 6-7, intro. notes (1981) (stating that noncontractual transfers, such as money paid to the wrong party or performance rendered by mistake, are addressed in a separate body of law covered by the Restatement of Restitution); see also id. ch. 16, topic 4, intro. note ("This Chapter does not deal with restitution in general, because that subject is covered by the Restatement of Restitution.").

325. See 3 PALMER, supra note 242 , at $\$ 14.3$, at 155 . The same rule applies in cases of fraud. See F.T.C. v. Think Achievement Corp., 144 F. Supp. 2d 1013, 1021 (N.D. Ind. 2000) (holding that the perpetrator of fraud must disgorge the entire amount received from consumer victims).

326. See 3 PALMER, supra note 242, § 14.3, at 156-57; see also RESTATEMENT (FIRST) OF RESTITUTION $\$ 160$ (1937) ("Where a person holding title to property is subject to an equitable duty to convey it to another on the ground that he would be unjustly enriched if he were permitted to retain it, a constructive trust arises.").

327. See Nickel v. Bank of Am. Nat. Trust and Sav., 290 F.3d 1134, 1138 (9th Cir. 2002) ("The elementary rule of restitution [for fraud] is that if you take my money and make money with it, your profit belongs to me."); see also RESTATEMENT (FIRST) OF RESTITUTION § $157 \mathrm{cmt}$. d (1937) ("If the recipient obtained land by fraud, duress, or other consciously tortious means, the claimant is entitled, at his election, to receive its income or the reasonable value of its use ...."); id.\$160 cmt. d ("[W] here the defendant makes a profit through the consciously wrongful disposition of the plaintiff's property, he can be compelled to surrender the profit to the plaintiff and not merely to restore to the plaintiff his property or its value ....").

328. See Restatement (ThIRD) OF Restitution AND UNJUST ENRICHMENT $\$ 3 \mathrm{cmt}$ c c (2011) ("Restitution requires full disgorgement of profit by a conscious wrongdoer, not just because of the moral judgment implicit in the rule of this section, but because any lesser liability would provide an inadequate incentive to lawful behavior.").

329. In some cases, the defendant must also pay plaintiff a fair amount for defendant's temporary use or possession of the plaintiff's assets, but again, this is not punitive. It is merely a court-imposed fair trade.

330. Perhaps disgorgement of profits is not a true deterrent because it leaves the defendant no worse off than if he had not committed the fraudulent act, but at the very least, it removes an incentive to commit fraudulent acts. 


\section{Summary on Remedies}

A combined defense of misconception should continue to couple rescission with restitution. In cases of pure mistake-those involving no false assertion - and cases of nonfraudulent misrepresentation, there is no normative need for deterrence or punishment, so disgorgement of profits and punitive damages are unnecessary. In cases of misconception arising from fraudulent misrepresentation, however, deterrence justifies disgorgement of profits. Finally, courts should also have the option of awarding punitive damages to both punish and deter fraud. Although this formulation of remedies reintroduces fraud as a separate concept, the inefficiency created by retention of this distinction at the remedies phase is offset by normative gains elsewhere. In its current formulation, the defense of fraudulent misrepresentation is no more effective at deterring or punishing nonnormative behavior than the defense of mistake. Allowing a broader range of remedies in the context of a combined defense creates efficiency in courts' decisions on the availability of the defense, and also provides greater consistency between the positive law of fraud and its normative underpinnings in the remedies stage of the case.

\section{CONCLUSION}

The contract defenses of mistake and misrepresentation, as they are currently construed by courts, contain an inefficient amount of overlap. Recall our opening example of Betty and Sam. If Betty buys Sam's business under the misconception that his accounting methods were sound, the monetary harm to her is the same regardless of the source of her misconception. Under current law, if Sam has misled Betty, she may avoid the contract of sale through the defense of misrepresentation. But why not mistake? Betty believed Sam's false assertion of fact, and as a result, she labors under a false belief during bargaining. ${ }^{331}$ Sam's misrepresentation, then, has instigated a case of mistake. ${ }^{332}$ In such a case, both misrepresentation and mistake might provide a remedy. Put more formally, where one or both of the parties bargain with reference to a fundamental misconception of the facts, the exchange to which they consent does not truly exist, and their relationship will produce a different balance of equities than was expected at the time of bargaining. ${ }^{333}$ Because both doctrines seek to remedy the same failure of consent, the legal test for avoidance on grounds of misrepresentation should be the same as that for mistake. In short, two defenses are not needed to remedy a single category of harm..$^{334}$

331. See supra Part III.A.

332. See CARTWRIGHT, supra note 146 , at 2.

333. See supra note 155.

334. One can imagine other areas where a single harm could merit provision of a remedy through multiple avenues. For instance, assume that my leg is broken through the fault of another. Maybe I was hit by Lolly the Trolley, involved in a bar fight with a Michigan fan, or slipped on a misplaced ba- 
Although modern iterations of the two defenses look quite different on paper, a review of case law suggests that the language employed by courts is vague. ${ }^{335}$ As a result, courts have a great deal of discretion in their application of the defenses, and their decisions demonstrate an array of possible outcomes under either defense that could be reached under both of them. This is because misrepresentation's requirements for materiality and inducement are largely coextensive with mistake's requirement of a basic assumption that materially affects the performances of the parties. ${ }^{336}$ Similarly, misrepresentation's inquiry into justified reliance by the adversely affected party is largely similar to mistake's allocation of risk. ${ }^{337}$ And while allocation of risk is a broader concept than justified reliance, nothing would prevent courts from reaching a fair result by accounting for a counterparty's misrepresentation in their risk allocation process under a combined defense. For example, if Betty's accountant reviews Sam's books and cannot determine whether they are accurate, we may presume that Betty has taken this fact under advisement. Perhaps she offered a lower price or extracted other concessions from Sam to offset the negative value of the risk presented by Sam's potentially faulty record-keeping. In such a case, justice does not require a court to help Betty when the bargained-for risk materializes. But if Sam assures Betty that the books are sound, she may include his assurance in her assessment of the magnitude of the risk, giving the court a reason to question the validity of her consent to the bargain. As a result, mistake's focus on assumption of risk and misrepresentation's focus on justified reliance are not so incompatible as to preclude the adoption of a single defense. In short, there is no compelling mechanical justification for the preservation of separate tests to determine the availability of rescission in cases of mistake and misrepresentation. Courts, or preferably, state legislatures, should employ a combined test of misconception to determine the availability of rescission in these cases.

Finally, normative justifications urge the preservation of fraud as a separate concept in contract law. ${ }^{338}$ Although Betty's bottom line is the same regardless of whether Sam intended to mislead her, she will experience an innocent mistake much differently than an intentional act of fraud. In fraud, one party has intentionally deprived another person of free will in bargaining. As such, fraud produces an additional dignitary harm that is not present in other instances of misconception. Infliction of this dignitary harm justifies punishment if Sam has deliberately lied to Betty. In addition, fraud may also chill the formation of future contracts between other parties and therefore calls for deterrence. The current

\footnotetext{
nana peel at the dog circus. Because the production of harm differs in each case, different legal tests apply to determine whether my harm can be remedied. The same is not true where a misrepresentation results in mistake. In such a case, the misrepresentation is the sole cause of the adverse effect.

335. See supra Part III.

336. Id.

337. Id.

338. See supra Part IV.D.
} 
remedies for misrepresentation-rescission alone, or rescission coupled with disgorgement of profits - do not adequately achieve these goals, as they inflict only reputational harm and leave the bad actor in a financial position that is no worse than if the fraud had not been committed. ${ }^{339}$ Consequently, in cases where the defense of misconception arises as a result of fraud, courts should have access to remedies that are punitive and deterrent. Both tort law and state statutory law allow punitive damages for fraud in some contexts, harmonizing its normative underpinnings of the law with its descriptive effect. A combined defense of misconception should do the same in contract law.

In closing, a combined defense of misconception that provides courts with discretion to award punitive damages in cases of fraud would create a more efficient resolution to cases of mistake and misrepresentation. This resolution would better serve the normative goals underlying the current defenses of mistake and misrepresentation by providing a simpler, more efficient test for rescission in all cases while more effectively accomplishing the goals of punishment and deterrence in cases of fraud. 